Hate Speech on Platforms 



\section{Protecting Democratic Expression Online: Canada's Work in Progress}

Richard Janda"

Abstract: In June, 2021, Canada's federal government finally introduced a part of its promised legislation to combat online hate speech. However, this bill, introduced on the last day Parliament sat before an election, was destined to "die on the order paper". Furthermore, the ambitious goal of creating a regulator for online platforms was postponed, although detailed consultation papers were issued in July, 2021. Thus, it has proved harder than anticipated to strike the balance between dismantling barriers to full democratic expression placed upon groups targeted by hate speech, on the one hand, and ensuring that platforms not be pushed toward zealous takedown practices, on the other. This article reviews Canada's existing legal framework, recent reports that are orienting policy options, the new bill, and the consultations papers issued by the government concerning additional new legislation. It concludes with some observations about how Canada could reinforce online dispute resolution and help shift platform business models that serve to amplify extreme content.

Keywords: online hate, platform governance, duty to act responsibly, social media councils, notice and takedown, online dispute resolution

There is something revealing about the very existence of this article. As texts were being gathered by the editors to present a comparative understanding of platform regulation, Canada was in the midst of formulating new legislation on online hate speech. Indeed, the Minister of Canadian Heritage had been given, on January 15, 2021, a new mandate by the Prime Minister to: ${ }^{1}$

* I am grateful to Judit Bayer, Lex Gill, Vivek Kirshnamurthy, and Taylor Owen for their assistance in the preparation of this article, though of course they bear no responsibility for any of its shortcomings.

1 Office of the Prime Minister of Canada, "Minister of Canadian Heritage Supplementary Mandate Letter,” January 15, 2021, https://pm.gc.ca/en/mandate-letters/2 
Work with the Minister of Public Safety and Emergency Preparedness and the Minister of Justice and Attorney General of Canada to take action on combatting hate groups and online hate and harassment, ideologically motivated violent extremism and terrorist organizations. You will be supported in this work by the Minister of Diversity and Inclusion and Youth, the Minister for Women and Gender Equality and Rural Economic Development and the Minister of Innovation, Science and Industry.

After the March 2019 terror attack in Christchurch, New Zealand, Canada had joined Christchurch Call to Action to address violent extremism online. ${ }^{2}$ In 2021, combatting extremism and hate speech was also presented as a matter of increasing priority in the wake of the Capitol Hill insurrection in Washington on January 6, and the Minister made multiple public statements to the effect the legislation would be forthcoming imminently, statements that continued to be made up to the moment when this article was submitted. ${ }^{3}$ The author thus fully expected to be writing about the nature and implications of the new Canadian regime.

021/01/15/minister-canadian-heritage-supplementary-mandate-letter. In his 2019 Mandate Letter, the Minister had already been charged to "[c]reate new regulations for social media platforms, starting with a requirement that all platforms remove illegal content, including hate speech, within 24 hours or face significant penalties. This should include other online harms such as radicalization, incitement to violence, exploitation of children, or creation or distribution of terrorist propaganda." Office of the Prime Minister of Canada, "Minister of Canadian Heritage Mandate Letter,” December 13, 2019, https://pm.gc.ca/en/mandate-letters/2019/12/13/minist er-canadian-heritage-mandate-letter.

2 Office of the Prime Minister of Canada, "Canada joins Christchurch Call to Action to eliminate terrorist and violent extremist content online," May 15, 2019, https:// pm.gc.ca/en/news/news-releases/2019/05/15/canada-joins-christchurch-call-action -eliminate-terrorist-and-violent. See Christchurch Call to Eliminate Terrorist and other Extremist Content Online, May 15, 2019, https://www.christchurchcall.com/ call.html.

3 See, for example Elizabeth Thompson, "Canada not exempt from social media forces that created U.S. Capitol riot, heritage minister says," CBC News, January 29, 2021, https://www.cbc.ca/news/politics/facebook-twitter-canada-regulation-1.5894 301, as well as Anja Karadeglija, "New definition of hate to be included in Liberal bill that might also revive contentious hate speech law," National Post, March 3, 2021, https://nationalpost.com/news/politics/new-definition-of-hate-to-be-include d-in-liberal-bill-that-might-also-revive-contentious-hate-speech-law, and Bill Curry and Menaka Raman-Wilms, "New internet bill on hate crime and revenge porn coming in 'very near future,' Guilbeault says," Globe \& Mail, June 7, 2021, https:// www.theglobeandmail.com/politics/article-new-internet-bill-on-hate-crime-and-rev enge-porn-coming-in-very-near/. 
And yet it was not to be - at least not entirely. The urgent, imminent legislation to establish a new regulator for online platforms continues to be a chimera. However, on the last day of sitting of the current minority Parliament, the Minister of Justice introduced Bill C-36 which would amend the Criminal Code and the Canadian Human Rights Act so as to address certain dimension of online hate speech. ${ }^{4}$ And just weeks before Canadians were called to vote in a general election, The Minister of Canadian Heritage released a Discussion Guide ${ }^{5}$ and Technical Paper, ${ }^{6}$ launching a public consultation about proposed legislation to be introduced in the fall of 2021 should the government be re-elected.

As a result, this article seeks to accomplish the following. First, it lays out in general terms the current state of Canadian law, which sets in context why the government - and the public - have concluded that there is need for legislative reform. Second, it describes and analyses reports that have been issued since 2019 aiming to pave the way for new legislation, with some emphasis on the work of the Canadian Commission on Democratic Expression, which issued an ambitious report in January 2021 just on the eve of the supplementary mandate issued to the Heritage Minister. Third, it assesses Bill C-36. Fourth, it gives an account of the Discussion Guide and Technical Paper that map out the approach the current government now proposes to take. Finally, it draws some lessons from the difficulties faced by the Minister in presenting this legislation, offering observations about the limits encountered when a state like Canada endeavours to create a new regulatory agency to control online speech.

This article is entitled "Protecting democratic expression online" rather than "Combatting online hate speech" so as to place emphasis upon the tension at play in seeking to eliminate harmful or dangerous forms of expression. The spread of hatred online can and indeed has transformed democratic expression into the sort of factionalism feared by James Madison, which he defined as arising when a group in "united and actuated

4 Bill C-36, An Act to amend the Criminal Code and the Canadian Human Rights Act and to make related amendments to another Act (hate propaganda, hate crimes and hate speech), 2d sess., 43d Parliament, June 23, 2021, https://www.parl.ca/LegisInfo/Bill Details.aspx?Bill=C36\&Language=E $\&$ Mode $=1 \&$ Parl $=43 \& S e s=2$.

5 Digital Citizen Initiative, Department of Canadian Heritage, "Discussion Guide," July 26, 2021, https:/www.canada.ca/en/canadian-heritage/campaigns/harmful-onli ne-content/discussion-guide.html.

6 Digital Citizen Initiative, Department of Canadian Heritage, "Technical Paper," July 26, 2021, https:/www.canada.ca/en/canadian-heritage/campaigns/harmful-onli ne-content/technical-paper.html. 
by some common impulse of passion" and the effects of which, if left without response, could turn a republic into a mob. ${ }^{7}$ On the other hand, the same James Madison, an architect of the First Amendment to the US Constitution, took a dim view of any prior restraints or ex post facto penalties imposed on publications. ${ }^{8}$ Madison's opposing concerns help to frame the issues raised here.

7 James Madison, Federalist No.10, in The Federalist Papers, ed. Clinton Rossiter (New York: New American Library, 1961), https://avalon.law.yale.edu/18th_century/fed1 0.asp. See also Jeffrey Rosen, “America is Living James Madison's Nightmare,” The Atlantic, October, 2018, https://www.theatlantic.com/magazine/archive/2018/10/ja mes-madison-mob-rule/568351/.

8 In his "Report on the Virginia Resolutions," Madison insisted on constitutional protection against state encroachments upon freedom of the press: "This security of the freedom of the press requires that it should be exempt not only from previous restraint by the Executive, as in Great Britain, but from legislative restraint also; and this exemption, to be effectual, must be an exemption not only from the previous inspection of licensers, but from the subsequent penalty of laws." James Madison, "Report on the Virginia Resolutions," January, 1800, https://press-pubs.u chicago.edu/founders/documents/amendI_speechs24.html. See also David Sentelle, "Freedom of the Press: A Liberty for All or a Privilege for a Few?" Cato Supreme Court Review (2014): 25. Nonetheless, it is obviously important to distinguish a late $18^{\text {th }}$ century conception of freedom of the press from the contemporary challenge posed by online platforms. Madison, who himself made sophisticated and influential use of the press, had imagined a "class of literati" who would become "cultivators of the human mind - the manufacturers of useful knowledge - the agents of the commerce of ideas - the censors of public manners - the teachers of the arts of life and the means of happiness." James Madison, "Notes for the National Gazette Essays" (ca. December 19, 1791-March 3, 1792), https://founders.archives.gov/?q= literati\%20\%22useful\%20knowledge $\% 22 \& s=1111311111 \& \mathrm{r}=1$. Given its freedom and elevated by such a class of literati, the press itself would serve to mediate and constrain the possible excesses of speech. See Colleen Sheehan, "The Politics of Public Opinion: James Madison's 'Notes on Government', William and Mary Quarterly 49, no. 4 (1992) 621. Extreme expression on the internet is not mediated by internet literati. 


\section{Canada's existing legal framework ${ }^{9}$}

Prof. Natasha Tusikov has remarked that Canada "is continuing to outsource regulation to commercial platforms." ${ }^{10}$ It is fair to point out that although Canada does have a relatively robust criminal law framework to address hate speech, it has lagged behind other jurisdictions in developing tools to address the online phenomenon. ${ }^{11}$ The brief review here of Canada's existing legal framework will touch upon the following elements: a) the absence of an equivalent to Germany's NetzDG regime; b) the all-but non-existent current role for Canada's communications, human rights and privacy agencies; c) the restricted reach of criminal law; and d) the constraints imposed by the Canada-U.S.-Mexico Trade Agreement.

\section{a. No equivalent to NetzDG}

Canada does not currently have any functional equivalent to the German NetzDG legislation requiring takedown by platforms of "manifestly unlawful" content. ${ }^{12}$ Interestingly, though, Canada does have experience with a quasi-takedown regime in the form of what is called "notice and notice" under the Copyright Act. ${ }^{13}$ Pursuant to s. 41.26 , an internet service provider

9 See the excellent review of the "Legal Aspects of Hate Speech" by Lex Gill prepared for the Canadian Commission on Democratic Expression, https://ppforum .ca/wp-content/uploads/2020/07/1.DemX_LegalAspects-EN.pdf. See also Sonja Solomun, Maryna Polataiko, and Helen A. Hayes, "Platform Responsibility and Regulation in Canada: Considerations on Transparency, Legislative Clarity, and Design," Harvard Journal of Law and Technology (Digest)) 34 (2021): 1-18, https://jol t.law.harvard.edu/digest/platform-responsibility-and-regulation-in-canada-conside rations-on-transparency-legislative-clarity-and-design.

10 Natasha Tusikov, "U.K. and Australia move to regulate online hate speech, but Canada lags behind," National Post, April 11, 2019, https://nationalpost.com/pm n/news-pmn/u-k-and-australia-move-to-regulate-online-hate-speech-but-canada-la gs-behind. See also Natasha Tusikov, Chokepoints: Global Private Regulation on the Internet, (Oakland: University of California Press, 2017).

11 The discussion in this section focuses upon hate speech and does not touch upon content inciting violence, terrorist content, child pornography, or non-consensual sharing of intimate images, to which criminal law and administrative law apply.

12 Available in translation as Germany, Network Enforcement Act, section 3, https:// www.bmjv.de/SharedDocs/Gesetzgebungsverfahren/Dokumente/NetzDG_engl.p $\mathrm{df}$ ?_blob=publicationFile $\& \mathrm{v}=2$.

13 Copyright Act, Revised Statutes of Canada, 1985, c. C-42, https://laws-lois.justice.gc.c a/eng/acts/c-42/. 
("ISP") that receives notice of a claimed copyright infringement (e.g. illegal downloading of a movie) shall "forward the notice electronically to the person to whom the electronic location identified by the location data specified in the notice belongs and inform the claimant of its forwarding." The ISP shall also "retain records that will allow the identity of the person to whom the electronic location belongs to be determined", typically for a period of six months. There is some evidence that parallel provisions of the US Digital Millennium Copyright Act have given rise to "surprisingly high percentages of notices of questionable validity, with mistakes made by both 'bots' and humans." 14 Indeed, the original Canadian version of the notice and notice regime attracted criticism that "notices using threatening language, making outrageous claims of liability, and making offers of settlement that were excessive and required the recipients disclose their personal information" and were thus serving to restrict permitted expression. ${ }^{15}$ This ultimately gave rise to amendments in 2018 specifying that notice could not contain such statements and allowing ISPs not to forward notices including pressure of that sort. ${ }^{16}$

Thus, even in advance of establishing any takedown regime for online hate speech, Canada has some experience with the perils of implementing a regime that could lead to an overly broad chilling effect on legitimate postings.

\section{b. All-but non-existent role of government agencies}

There are three potential sources of regulatory oversight of online hate speech in Canada: the Canadian Radio-television and Telecommunications Commission (CRTC), provincial and federal human rights commissions, and provincial and federal privacy commissioners. None of these instances have developed a significant role in this domain.

14 See Jennifer M. Urban, Joe Karaganis and Brianna L. Schofield, "Notice and Takedown in Everyday

Practice" UC Berkeley Public Law Research Paper, No. 2755628, March 24, 2017, https://papers.ssrn.com/sol3/papers.cfm?abstract_id=2755628.

15 Michal Jaworski and Athar Malik, "Did You Notice? When A Notice Is Not A Notice Under The Notice And Notice Regime, „March 27, 2019, https:/www.mo ndaq.com/canada/copyright/792094/did-you-notice-when-a-notice-is-not-a-notice -under-the-notice-and-notice-regime.

16 Copyright Act, s. 41.25(3). 
For its part, the CRTC has a statement on its website explaining its forbearance from regulating internet content: ${ }^{17}$

The CRTC does not regulate internet content because consumers can already control access to unsuitable material on the internet using filtering software. Any potentially illegal content on the internet can be addressed with civil action, existing hate crime legislation, and the courts.

It should be noted, however, that the Broadcasting Distribution Regulations adopted pursuant the Broadcasting Act provide that: ${ }^{18}$

8 (1) No licensee shall distribute a programming service that the licensee originates and that contains

(b) any abusive comment or abusive pictorial representation that, when taken in context, tends to or is likely to expose an individual or group or class of individuals to hatred or contempt on the basis of race, national or ethnic origin, colour, religion, sex, sexual orientation, age or mental or physical disability

In principle, the distribution of such content by a licensee can lead to fines and even to the removal of the license by the CRTC. Although there is currently a bill before Parliament to amend the Broadcasting Act that would extend the definition of "broadcasting undertaking" to include "an online undertaking," the CRTC would not be empowered to establish a class of licences for such online undertakings. ${ }^{19}$ Thus, the current Broadcasting Distribution Regulations would not give the CRTC regulatory authority over hate speech distributed by online undertakings. Nonetheless, the bill would grant discretion to the CRTC to develop conditions applicable to all broadcasting undertakings, including online undertakings, "that the Commission considers appropriate for the implementation of the broadcasting policy set out in subsection 3(1)." ${ }^{20}$ In principle the CRTC could

17 Canadian Radio-television and Telecommunications Commission (CRTC), "Frequently asked questions," April 1, 2015, https://crtc.gc.ca/eng/faqs.htm.

18 Broadcasting Distribution Regulations, SOR/97-555, https://laws.justice.gc.ca/eng/re gulations/SOR-97-555/page-3.html\#h-1010707.

19 Bill C-10, An Act to amend the Broadcasting Act and to make related and consequential amendments to other Acts, 2d sess., 43d Parliament, November 3, 2020, ss. 1(1) and 6(1)(a), https://parl.ca/DocumentViewer/en/43-2/bill/C-10/first-reading\#ID0 E02B0AA. For a discussion of this proposed legislation see the article by Michael Geist in this collection.

20 Bill C-10, s. 9.1. 
therefore develop a code of conduct parallel s. 8 of the Broadcasting Distribution Regulations.

The Canadian Human Rights Commission, for its part, until 2013 oversaw section 13 of the Canadian Human Rights Act which then provided (emphasis added): ${ }^{21}$

13 (1) It is a discriminatory practice for a person or a group of persons acting in concert to communicate or to cause to be so communicated, repeatedly, in whole or in part by means of the facilities of a telecommunication undertaking within the legislative authority of Parliament, any matter that is likely to expose a person or persons to hatred or contempt by reason of the fact that that person or those persons are identifiable on the basis of a probibited ground of discrimination.

Interpretation

(2) For greater certainty, subsection (1) applies in respect of a matter that is communicated by means of a computer or a group of interconnected or related computers, including the Internet, or any similar means of communication, but does not apply in respect of a matter that is communicated in whole or in part by means of the facilities of a broadcasting undertaking.

Interpretation

(3) For the purposes of this section, no owner or operator of a telecommunication

undertaking communicates or causes to be communicated any matter described in subsection (1) by reason only that the facilities of a telecommunication undertaking owned or operated by that person are used by other persons for the transmission of that matter.

This provision was repealed by a private member's bill that notably had the support of the Canadian Civil Liberties' Association largely on the grounds that it had infringed upon free speech. ${ }^{22}$ The repeal arose under the previous Conservative government despite the fact that the Federal Court of Appeal had upheld the constitutional validity of the provision. ${ }^{23}$

21 Canadian Human Rights Act, Revised Statutes of Canada, 1985, c. H-6, archived version, https://laws-lois.justice.gc.ca/eng/acts/h-6/section-13-20021231.html\#: :tex $\mathrm{t}=13 \% 20$ (1)\%20It\%20is\%20a,Parliament\%2C\%20any\%20matter\%20that\%20is.

22 See Joel Webe, "Hate speech no longer part of Canada's Human Rights Act" National Post, June 27, 2013, https://nationalpost.com/news/politics/hate-speech-n o-longer-part-of-canadas-human-rights-act.

23 Lemire v. Canada (Human Rights Commission), 2014 FCA 18, https://canlii.ca/t/g2x $2 \mathrm{~d}$. 
Since the repeal of s. 13, the Canadian Human Rights Commission has periodically made public statements about the need to address online hate but has not engaged in any enforcement strategy. ${ }^{24}$

Provincial human rights commissions do not have the equivalent to the former s. 13 and have thus had to rely upon general anti-discrimination protections to pursue online hate speech, something they have seldom ever done. In 2015, the then Minister of Justice of Québec proposed legislation that would have added a hate speech regime to the Québec Charter of Human Rights and Freedoms giving rise to remedies and enforcement by the Quebec Human Rights Commission. ${ }^{25}$ However, the government eventually backed away from the proposal, with the Commission for its part recommending the introduction of such a regime but cautioning against potential overreach. ${ }^{26}$ Since that time, and in the wake of a horrific mass shooting at a mosque in Quebec City, the Commission was tasked with conducting a study on hateful acts, notably those motivated by islamophobia, in which it underscored the proliferation of hate speech on the internet. ${ }^{27}$ However, the Commission also noted that most cases are not reported to authorities, and for those that are it was typically very difficult to trace the origin of the message to an individual. ${ }^{28}$

For a comment on the consistency of s. 13 with human rights protection, see Pearl Eliadis, "The Controversy Entrepreneurs," Maisonneuve, August 20, 2009, https://maisonneuve.org/article/2009/08/20/controversy-entrepreneurs/.

24 See for example, Canadian Human Rights Commission, "Statement - We must do more to curb online hate," January 21, 2021, https://www.chrc-ccdp.gc.ca/en/r esources/statement-we-must-do-more-curb-online-hate.

25 Projet de loi 59, Loi édictant la Loi concernant la prévention et la lutte contre les discours haineux et les discours incitant à la violence et apportant diverses modifications législatives pour renforcer la protection des personnes, $1^{\mathrm{er}}$ sess., $42^{\mathrm{e}}$ législature, June 10 , 2015, http://m.assnat.qc.ca/fr/travaux-parlementaires/projets-loi/projet-loi-59-41-1. html.

26 See Commission des droits de la personne et des droits de la jeunesse, Mémoire à la Commission des institutions de l'Assemblée nationale, August 2015, https://www.c dpdj.qc.ca/storage/app/media/publications/memoire_PL59_discours-haineux.pdf.

27 Commission des droits de la personne et des droits de la jeunesse, Les actes haineux à caractère xénophobe, notamment islamophobe : résultats d'une recherche menée à travers le Québec, August, 2019, 111, https:/www.cdpdj.qc.ca/storage/app/ media/publications/etude_actes_haineux.pdf.

28 Commission des droits $\overline{\mathrm{de}}$ la personne et des droits de la jeunesse, Les actes haineux, $186 \mathrm{ff}$. and 249. 
To pursue the Québec example further, section 11 of the Québec Charter of Human Rights and Freedoms specifies that:

No one may distribute, publish or publicly exhibit a notice, symbol or sign involving discrimination, or authorize anyone to do so.

The Québec Human Rights Tribunal has found that a message reading "Landlords Go Home" addressed to persons of Haitian origin violated s. 11 and gave rise to damages. ${ }^{29}$ In principle this kind of case suggests a pathway toward civil remedies against online hate if the person at the origin of the message can be identified.

Although Canada's Privacy Commissioner has commented publicly on the issue of online hate speech, the role of the Commissioner's office is currently all but non-existent. ${ }^{30}$ However, Lex Gill has noted that to the degree platforms adopt algorithmic approaches to screening online hate: ${ }^{31}$

content filtering and censorship technology is almost always surveillance technology

as well. It is therefore rare that the adoption of such measures will not involve at least indirect impacts on users' privacy rights.

Furthermore, the business model of platforms is focused on keeping users engaged (addicted) and collecting as much data from them as possible so as to increase advertising revenue. ${ }^{32}$ This business model tends to amplify the spread of extreme content. ${ }^{33}$ Under proposed new Canadian legislation, modelled on the California Consumer Privacy Act, ${ }^{34}$ the Privacy Commissioner and a new Data Protection Tribunal would have significantly augmented enforcement powers, including to impose fines of up to $3 \%$ of the organization's yearly gross global revenue. These powers would en-

29 Commission des droits de la personne et des droits de la jeunesse (Coffy et une autre) c. Brisson, 2009 QCTDP 3, https://canlii.ca/t/22qhm.

30 See Office of the Privacy Commissioner of Canada, "A Data Privacy Day Conversation with Canada's Privacy Commissioner,” January 28, 2020, https://www.priv. gc.ca/en/opc-news/speeches/2020/sp-d_20200128/.

31 Gill, "Legal Aspects of Hate Speech," 15.

32 Andrew Burt, "Can Facebook Ever be Fixed?," Harvard Business Review, April 8, 2019, https://hbr.org/2019/04/can-facebook-ever-be-fixed.

33 Gilad Edelman, "Social Media CEOs Can't Defend Their Business Model,” Wired, March 25, 2021, https://www.wired.com/story/social-media-ceo-hearing-cant-defe nd-business-model/.

34 California Code, Title 1.81.5. California Consumer Privacy Act of 2018, https://leginf o.legislature.ca.gov/faces/codes_displayText.xhtml?division=3.\&part=4.\&lawCode $=$ CIV\&title $=1.81 .5$. 
force a range of requirements touching digital platforms directly, notably that companies must:

- only collect personal information for an appropriate purpose;

- not require consent to the collection of personal information beyond what is needed for the provision of a service;

- not obtain consent by a misleading practice;

- not retain personal information for longer than needed to fulfill the purpose for which it was collected;

- dispose of personal information collected by them from users if users withdraw consent to its use; and

- protect personal information through security safeguards. ${ }^{35}$

The bolstered privacy regime has the potential to disrupt the business model of digital platforms and thus, indirectly, to have an impact on the spread of online hate. ${ }^{36}$ This point will be contextualized somewhat further in the fourth part of this article.

\section{c. Criminal law provisions}

Canada's Criminal Code contains a number of prohibitions touching upon hate speech: advocating genocide (s. 318); publicly inciting hatred (s. 319(1)); and promoting hatred (s. 319(2)). ${ }^{37}$ These provisions have been found consistent with constitutional protections of free speech. ${ }^{38}$

Although the dataset is incomplete, Statistics Canada has reported that there were only some 50 police-reported online cases per year across Cana-

35 Bill C-11, Digital Charter Implementation Act, 2020, 2d sess., 43d Parliament, November 17, 2020, https://parl.ca/DocumentViewer/en/43-2/bill/C-11/first-r eading. See also the parallel proposed Quebec legislation, which with respect to the "right to de-indexation" and the "right to be forgotten" goes further than the federal legislation: Projet de loi 64, Loi modernisant des dispositions législatives en matière de protection des renseignements personnels, $1^{\mathrm{er}}$ sess., $42^{\mathrm{e}}$ legislature, June 12 , 2020, http://m.assnat.qc.ca/fr/travaux-parlementaires/projets-loi/projet-loi-64-42-1. html.

36 See Jon Swartz, "California's landmark privacy law is Facebook's next 'nightmare'," Market Watch, August 22, 2020, https://www.marketwatch.com/story/calif ornias-landmark-privacy-law-is-facebooks-next-nightmare-2020-08-18.

37 Criminal Code, Revised Statutes of Canada, 1985, c. C-46, https://laws-lois.justice.gc. ca/eng/acts/c-46/.

38 See notably $R v$ Keegstra, [1990] 3 SCR 697, https://scc-csc.lexum.com/scc-csc/scc-c sc/en/item/695/index.do. 
da, with no records kept on successful prosecutions. ${ }^{39}$ Police forces have noted that they face major resource constraints investigating and prosecuting these crimes, which confront them with significant technical obstacles involving encryption and the generalized use of virtual private networks. ${ }^{40}$

There are two other areas of Canadian criminal law relating to online hate speech. The Protecting Canadians from Online Crime Act of 2014 added a new offence prohibiting non-consensual distribution of intimate images including (s. 162.1) as well as complementary amendments to authorize the removal of such images, including child pornography, from the Internet (s. 164.1(5)) and the restriction of the use of a computer or the Internet by a convicted offender (s. 162.2). ${ }^{41}$ The Anti-Terrorism Act of 2015 amended the Criminal Code to add a prohibition against counselling another person to commit a terrorism offence (s. 83.221.). ${ }^{42}$ Furthermore, a judge may order that "terrorist propaganda" available to the public be deleted from a computer system (s. 83.223).

\section{d. The Canada-U.S.-Mexico Trade Agreement}

Article 19.17 of the Canada-U.S.-Mexico Trade Agreement (in force 2020) all but extends Section 230 of the U.S. Communications Decency Act to Canada by providing: ${ }^{43}$

39 House of Commons, Standing Committee on Justice and Human Rights, Taking Action to End Online Hate, June, 2019, 21, https:/www.ourcommons.ca/Content/ Committee/421/JUST/Reports/RP10581008/justrp29/justrp29-e.pdf. A review of the caselaw on www.canlii.org reveals 5 successful reported prosecutions over the last 5 years.

40 See Canadian Commission of Democratic Expression, Harms Reduction: A Six-Step Program to Protect Democratic Expression Online, Public Policy Forum, January, 2021, 21, https://ppforum.ca/wp-content/uploads/2021/01/CanadianCommission OnDemocraticExpression-PPF-JAN2021-EN.pdf.

41 Protecting Canadians from Online Crime Act, Statutes of Canada, 2014, c. 31, https:// laws-lois.justice.gc.ca/eng/annualstatutes/2014_31/FullText.html.

42 Anti-Terrorism Act of 2015, Statutes of Canada, 2015, c. 20, https://laws-lois.justice.g c.ca/eng/annualstatutes/2015_20/page-3.html\#h-20.

43 Canada-U.S.-Mexico Trade Agreement, Article 19.17.1, https://www.international.gc .ca/trade-commerce/trade-agreements-accords-commerciaux/agr-acc/cusma-aceum /text-texte/19.aspx?lang=eng. By contrast, U.S. Communications Decency Act, U.S. Code 47 (2018) \$230(c) provides: "No provider or user of an interactive computer service shall be treated as the publisher or speaker of any information provided by another information content provider." 
no Party shall adopt or maintain measures that treat a supplier or user of an interactive computer service as an information content provider in determining liability for harms related to information stored, processed, transmitted, distributed, or made available by the service, except to the extent the supplier or user has, in whole or in part, created, or developed the information.

This entails that Canada cannot treat online platforms as providing user-generated content and treat them as liable for harms caused by that content. ${ }^{44}$

There is some question as to how much this provision will constrain any new Canadian online hate speech regime. Krishnamurthy and Fjeld have argued that by contrast with Section 230, which bars all causes of action against a platform that treat it as "publisher or speaker" of hosted information, Article 19.17 only excludes it from being held "liable," thus according to them opening the possibility of "equitable" remedies including restraining orders and injunctions. ${ }^{45}$ Notice and takedown would thus be possible.

It should be added that a regulatory framework applying to online platforms, including, for example a duty to act responsibly in overseeing its own community standards, which might be accompanied by enforcement powers including fines, should not in principle run afoul of Article 19.17 as long as it does not impose liability on platforms (i) in the same way as it does to content providers and (ii) for steps taken by platforms themselves to control "harmful or objectional" content.

The former point suggests that the CRTC should be cautious before using any new powers acquired pursuant to Bill C-10 simply to extend to online platforms the regime applicable to broadcasting licensees under the Broadcasting Distribution Regulations. ${ }^{46}$ Even were it to do so, however, it is arguable that those regulations give rise to equitable remedies rather than to a liability regime.

44 Article 19.17.4 makes clear that the Article does not apply to the protection of intellectual property rights or to the enforcement of criminal law.

45 For a detailed discussion, see Vivek Krishnamurthy and Jessica Fjeld, "CDA 230 Goes North American? Examining the Impacts of the USMCA's Intermediary Liability Provisions in Canada and the United States," SSRN, July 7, 2020, https:// ssrn.com/abstract $=3645462$.

46 See supra notes 17 to 20 and accompanying discussion. 
This latter point is underscored by Article 19.17.3:

No Party shall impose liability on a supplier or user of an interactive computer service on account of:

(a) any action voluntarily taken in good faith by the supplier or user to restrict access to or availability of material that is accessible or available through its supply or use of the interactive computer services and that the supplier or user considers to be harmful or objectionable; or (b) any action taken to enable or make available the technical means that enable an information content provider or other persons to restrict access to material that it considers to be harmful or objectionable.

This provision emphasizes immunity from liability for platforms on what might be called a "Good Samaritan" basis: where platforms make good faith efforts to control harmful or objectional material, they should not be held liable for those actions. However, if for example a regulatory requirement is imposed on platforms to take steps to restrict access to harmful or objectional material, and the platform fails to comply, it could not invoke Article 19.17.3 as a shield. It would no longer be operating in the realm of voluntary corporate social responsibility: it would be subject to legal constraints.

\section{Reports on directions for law reform}

The review of existing Canadian law makes clear that at best, Canada has a limited range of tools to address online hate speech and nothing resembling an overall legal framework to ensure that democratic expression is not undermined by the existence of filter bubbles that can concentrate and reinforce extreme expression. ${ }^{47}$ A survey conducted by the Canadian Race Relations Foundation in January, 2021 found that "93\% of Canadians believe that online hate speech and racism are a problem, including 49 percent who believe online hate speech and racism are very serious prob-

47 See Eli Paliser, The filter bubble: what the Internet is hiding from you, (New York: Penguin, 2011). See also Daniel Kilvington, "The virtual stages of hate: Using Goffman's work to conceptualise the motivations for online hate," Media, Culture \& Society 43, no. 2 (2020): 256-272, https://journals.sagepub.com/doi/10.1177/016 3443720972318. 
lems." 48 Furthermore, "the majority of Canadians-at least 60 percentbelieve that the federal government has an obligation to put forward regulation to prevent the spread of hateful and racist rhetoric and behaviour online," and "nearly 80 percent of Canadians said they would support regulation that would require social media companies to remove hateful or racist content from their platforms within 24 hours of it being posted.”

Not surprisingly, therefore, there have been a number of recent prominent reports and consultation papers paving the way for legislative reform. Six of them are singled out here for review: a) Taking Action to End Online Hate, the 2019 Report of the House of Commons Standing Committee on Justice and Human Rights; b) Canada's communications future: Time to act, the 2020 Report of the Broadcasting and Telecommunications Legislative Review Panel; c) Defamation Law in the Internet Age, the 2020 Report of the Law Commission of Ontario; d) Recommendations to Strengthen Canada's Response to New Digital Technologies and Reduce the Harm Caused by their Misuse, the 2021 Report of the Canadian Citizens' Assembly on Democratic Expression, and e) the Harms Reduction: A Six-Step Program to Protect Democratic Expression, the 2021 companion Report of the Canadian Commission on Democratic Expression. ${ }^{49}$

48 Canadian Race Relations Foundation, "Poll demonstrates support for strong social media regulations to prevent online hate and racism," January 25, 2021, https://www.crrf-fcrr.ca/en/news-a-events/media-releases/item/27349-poll-demons trates-support-for-strong-social-media-regulations-to-prevent-online-hate-and-racis m.

49 Two additional relevant reports are not treated in detail here. The wide-ranging 2018 Report of the House of Commons Standing Committee on Access to Information, Privacy and Ethics entitled Democracy under Threat: Risks and Solutions in the Era of Disinformation and Data Monopoly, Our Commons https://www.ourcom mons.ca/Content/Committee/421/ETHI/Reports/RP10242267/ethirp17/ethirp17-e .pdf touched upon the issue of notice and takedown and recommended (at 3) that "to remove manifestly illegal content in a timely fashion, including hate speech, harassment and disinformation, or risk monetary

sanctions commensurate with the dominance and significance of the social platform, and allowing for judicial oversight of takedown decisions and a right of appeal." See also Jacob Davey, Mackenzie Hart, Cécile Guerin, ed. Jonathan Birdwell, Interim Report: An Online Environmental Scan of Right-wing Extremism in Canada, The Institute for Strategic Dialogue, June 19, 2020, https://www.isdglobal.o $\mathrm{rg} / \mathrm{wp}$-content/uploads/2020/06/An-Online-Environmental-Scan-of-Right-wing-Ex tremism-in-Canada-ISD.pdf. The Report "identified 6,660 right-wing extremists channels, pages, groups and accounts across 7 social media platforms" operating in Canada (at 5). 


\section{a. Taking Action to End Online Hate}

The Standing Committee on Justice and Human Rights ("Committee"), which was composed of six voting members of the Liberal government, three from the Conservative opposition and one from the NDP opposition, chose to frame its Report with a pointed quotation from the reasons of Rothstein J. in the Supreme Court of Canada's Walcott decision: ${ }^{50}$

Hate speech is not only used to justify restrictions or attacks on the rights of protected groups on prohibited grounds ... hate propaganda opposes the targeted group's ability to find self-fulfillment by articulating their thoughts and ideas. It impacts on that group's ability to respond to the substantive ideas under debate, thereby placing a serious barrier to their full participation in our democracy. Indeed, a particularly insidious aspect of hate speech is that it acts to cut off any path of reply by the group under attack. It does this not only by attempting to marginalize the group so that their reply will be ignored: it also forces the group to argue for their basic humanity or social standing, as a precondition to participating in the deliberative aspects of our democracy.

A concern with the rise in hate crimes reported by the police as well as with the connection between online hate and acts of violence led the Committee to initiate a study in March of 2019. The Committee, chaired by Anthony Housefather of the Liberal Party, heard from forty groups and organizations, including Facebook, Twitter and Google, as well as nine individuals. The result was a report culminating in nine recommendations. The Conservative Party members of the Committee dissented from the Report $^{51}$ and the New Democratic Party ("NDP") issued a supplementary report essentially endorsing the general direction taken but proposing some further detail. ${ }^{52}$ Five of these recommendations concerned ways to improve existing mechanisms for combatting online hate, placing emphasis upon improved funding for training of police, crown attorneys and judges, better collection of data on hate crimes including via a national database on hate crimes and hate incidents, facilitation of reporting and

50 See Saskatchewan (Human Rights Commission) v. Whatcott, [2013] 1 SCR 467 at 507, https://scc-csc.lexum.com/scc-csc/scc-csc/en/item/12876/index.do?q=whatcott. Cited by House of Commons, Taking Action to End Online Hate, 5.

51 House of Commons, Taking Action to End Online Hate, 55-6.

52 House of Commons, Taking Action to End Online Hate, 57-61. 
public education. Without recommending specific language, the Committee urged: ${ }^{53}$

That the Government of Canada formulate a definition of what constitutes 'hate' or 'hatred' that is consistent with Supreme Court of Canada jurisprudence. It is critical that this definition acknowledges persons who are disproportionately targeted by hate speech including but not limited to racial, Indigenous, ethnic, linguistic, sexual orientation, gender identity, and religious groups.

The Committee also recommended that a civil remedy be established, perhaps by reinstating s. 13 of the Canadian Human Rights Act or some analogous measure. ${ }^{54}$ The Committee favoured the implementation of a timely notice and takedown regime, with platforms required to "make it simple for users to flag problematic content," but did not specify applicable standards. ${ }^{55}$ The NDP for its part favoured a "manifestly illegal" standard like that adopted in Germany's NetzDG, as well as "monetary sanctions commensurate with the dominance and significance of the social platform, and allowing for judicial oversight of takedown decisions and a right of appeal." 56 The Report placed considerable emphasis upon transparency, recommending common standards for platform reporting mechanisms and a duty to report regularly to users concerning incidents reported, actions taken, and the speed of response, which significant monetary penalties for failure to report. ${ }^{57}$ Finally, the Report signalled support for an effort to enhance the authentication of online content by recommending: ${ }^{58}$

That online platforms be encouraged to provide optional mechanisms to authenticate

contributors and digitally sign content, and couple this with visual indicators signifying

that given user or content is authenticated, and provide users options for filtering nonsigned or non-authenticated content.

53 House of Commons, Taking Action to End Online Hate, 41.

54 House of Commons, Taking Action to End Online Hate, 41.

55 House of Commons, Taking Action to End Online Hate, 42.

56 House of Commons, Taking Action to End Online Hate, 61. Note that this recommendation tracked the language House of Commons, Democracy under Threat Report, 349.

57 House of Commons, Taking Action to End Online Hate, 42.

58 House of Commons, Taking Action to End Online Hate, 42. 
It is worth noting, finally, as the Report itself underscored, that in its presentation to the Committee, Facebook supported "the establishment of clear baseline standards applicable to all platforms would help to counter online hate" since "people use many different online platforms to communicate". 59

\section{b. Canada's communications future: Time to act}

Although the Report of the Broadcasting and Telecommunications Legislative Review Panel was mainly of significance for the preparation of Bill $\mathrm{C}-10,{ }^{60}$ the Report did address the fact that "[o]nline platforms have ... created forums that enable the dissemination of harmful content, fake news and disinformation, and violent and extremist content." 61 One of the core recommendations, taken up in Bill C-10, was to ensure that the CRTC can impose codes of conduct "regarding all media content undertakings" - including online platforms. ${ }^{62}$ The Report also formulated a specific recommendation about liability for harmful content: ${ }^{63}$

We recommend that the federal government introduce legislation with respect to liability of digital providers for harmful content and conduct using digital technologies, separate and apart from any responsibilities that may be imposed by communication legislation. Given that the challenges in this area are global in nature, we also encourage the federal government to continue to participate actively in international fora and activities to develop international cooperative regulatory practices on harmful content.

59 House of Commons, Taking Action to End Online Hate, 27.

60 Bill C-10.

61 Broadcasting and Telecommunications Legislative Review Panel, Final Report, Canada's communications future: Time to act, January, 2020, https://www.ic.gc.ca /eic/site/110.nsf/vwapj/BTLR_Eng-V3.pdf/\$file/BTLR_Eng-V3.pdf. The Panel, appointed by the federal government, was chaired by Janet Yale, former CEO of the Canadian Cable television Association and a former Director General of the CRTC. Other panelists included lawyers Peter Grant, Hank Intven, and Monica Song, academics Marina Pavlović and Pierre Trudel, and Monique Simard, who had been CEO of the Société de développement des entreprises culturelles.

62 Broadcasting and Telecommunications Legislative Review Panel, 10 and 34.

63 Broadcasting and Telecommunications Legislative Review Panel, 37 as well as discussion at 190-193. 
Finally, it made a parallel recommendation with respect to illegal content and conduct: 64

We recommend that the federal government regularly review the efficiency of enforcement mechanisms for monitoring and removing illegal content and conduct found online. Given the diverse range of governing frameworks for these matters in Canada, we encourage the federal government to coordinate with provincial and territorial governments.

The Report has thus set the stage for a greater role for the CRTC in applying codes of conduct to online platforms but has at the same time envisaged a separate "liability" regime for online platforms (Article 19.17 of Canada-U.S.-Mexico Trade Agreement was not referenced) and placed considerable emphasis upon inter-governmental coordination.

\section{c. Defamation Law in the Internet Age}

The Law Commission of Ontario spent four years studying "how best to reform defamation law in response to the social and technological revolution in written communications brought about by the internet." 65 There is, of course, some significant overlap between defamatory speech and hate speech. The Commission made clear that it had "explored the role of defamation law in relation to an array of legal tools for regulating online speech in the 21st century" including "myriad laws directed at particular types of harmful speech, such as child pornography and hate speech." ${ }^{6}$ Nonetheless, the Commission excluded "direct examination of these related areas of law." 67

Taken as a whole, the Report contains three chapters with significant implications for the regulation of online hate speech and the protection

64 Broadcasting and Telecommunications Legislative Review Panel, 193.

65 Law Commission of Ontario, Defamation Law in the Internet Age, March 2020 at 1, https:/www.lco-cdo.org/wp-content/uploads/2020/03/Defamation-Final-Repo rt-Eng-FINAL-1.pdf. The Law Commission of Ontario was originally created by the Ontario Ministry of the Attorney General, the Law Foundation of Ontario, the Law Society of Ontario, Osgoode Hall Law School and the Law Deans of Ontario and is now funded by the Law Foundation of Ontario, the Law Society of Ontario, Osgoode Hall Law School, and York University: "Learn about us," https://www.lco-cdo.org/en/learn-about-us/.

66 Law Commission of Ontario, Defamation Law in the Internet Age, 15.

67 Law Commission of Ontario, Defamation Law in the Internet Age, 15. 
of democratic expression: chapters on new legal responsibilities for intermediary platforms, notice and takedown, and online dispute resolution. As to legal responsibilities, the Commission came to the conclusion that the existing common law framework imposing liability for defamation upon publishers is "clumsy and overinclusive when applied to the unique functioning of the internet." 68 The Commission produced an interesting table summarizing the reasons why platforms should not be liable for defamation: ${ }^{69}$

\section{Internet Intermediary Liability for Third Party Defamation}

\section{Illegitimate}

- Platforms become quasi-judicial decision-makers

\section{Unworkable}

- Platforms can't know whether a post is defamatory

\section{Unpredictable}

- There are endless ways platforms may be involved in third party content

\section{Undermines Corporate Social Responsibility}

- Platforms have an incentive to take a "hands off" approach to content

\section{Chills Free Speech}

- Platforms have an incentive to remove controversial content

Arguably each of these rationales applies as well to other forms of harmful content including hate speech. It is striking that the Commission was unimpressed by existing and evolving quasi-judicial processes established by platforms such as the Facebook Oversight Board. ${ }^{70}$ In the end, it rec-

68 Law Commission of Ontario, Defamation Law in the Internet Age, 74.

69 Law Commission of Ontario, Defamation Law in the Internet Age, 77.

70 See Facebook Oversight Board, https://oversightboard.com/. The Commission observed that "Although Facebook's Oversight Board contemplates some adjudicative elements, it is probably not a promising model of [online dispute resolution] ODR in the absence of a more direct focus on the interests of the parties. Furthermore, it does not contemplate any supervisory role for government." Law Commission of Ontario, Defamation Law in the Internet Age, 103. 
ommended that online platforms should be excluded from the category "publisher" by defining that term to "to require an intentional act of communicating a specific expression." 71

\section{The Commission also recommended that there be "a takedown obligation on intermediary}

platforms hosting third party content available to users in Ontario." 72 Notice of complaint would be forwarded by the platform to the publisher of the allegedly defamatory material. The publisher would then have two days to respond in writing. Where a response was received by the platform within the prescribed period, that response would be forwarded to the complainant and no further action would be taken, since the platform would be given no role in assessing the merits of the complaint. On the other hand, if no response was forthcoming, the platform would be required to take down the specific language that is alleged to be defamatory. Notice of takedown would be provided to the publisher, who could require put-back if "there is evidence that the publisher failed to receive the notice or unintentionally missed the deadline and where it is technologically reasonable to do so."73 Regulations would specify an administrative fee that platforms could charge to complainants. Failure by the platform to comply with takedown requirements would entitle the complainant to statutory damages. The Ontario Superior Court of Justice, the court of general jurisdiction, would enforce the notice and takedown regime.

Interestingly, the Commission specified that the regime would only apply to platforms hosting content available in Ontario and recommended excluding search engines from its ambit. Since the publication of the Report, Google has come under considerable pressure to intervene to prevent websites from running a successful business involving the publication of defamatory material that appears high in Google searches, in turn allowing these websites to charge thousands of dollars to victims to take the posts down. ${ }^{74}$ Google has announced that it will change its search algorithm to prevent predatory websites from appearing in the list of results when

71 Law Commission of Ontario, Defamation Law in the Internet Age, 80 and 109.

72 Law Commission of Ontario, Defamation Law in the Internet Age, 96 and 109.

73 Law Commission of Ontario, Defamation Law in the Internet Age, 96 and 109.

74 See Adam Krolik and Kashmir Gill, "The Slander Industry," New York Times, April 24, 2021, https://www.nytimes.com/interactive/2021/04/24/technology/onli ne-slander-websites.html. 
someone searches for a person's name, and that it has created a "known victims" service for those who report having been attacked by sites that charge for the removal of posts. ${ }^{75}$ After a report to the "known victims" service, Google will suppress similar content when someone searches for a victim's name. This represents an important departure for Google, since it had heretofore taken the position, parallel to that of the Commission, that "[w]e never touch search, no way, nohow."

The Commission was aware that its recommendations on notice and takedown arose in a context where there was increasing pressure on the federal government to enact a takedown regime for "manifestly illegal content," which could include defamation. ${ }^{77}$ While the Commission eschewed taking any position on the merits of proposals such as those contained in the Taking Action to End Online Hate Report, it did signal the relevance to the debate of proposals to create a statutory duty of care, underscoring in particular the importance of the 2019 UK White Paper on Online Harms. ${ }^{78}$

Finally, while the Commission expressed deep skepticism about the development of online dispute resolution by platforms themselves, characterizing them as having "few of the hallmarks of procedural fairness and none of the authoritativeness of a judicial decision," 79 it did consider a "coregulatory approach" 80 as well as the possibility of creating social media councils to be a "multi-stakeholder accountability mechanism for platform

75 See Kashmir Hill and Daisuke Wakabayashi, "Google Seeks to Break Vicious Cycle of Online Slander," New York Times, June 10, 2021, https://www.nytimes.co m/2021/06/10/technology/google-algorithm-known-victims.html.

76 Kashmir Hill and Daisuke Wakabayashi.

77 Law Commission of Ontario, Defamation Law in the Internet Age, 95.

78 Law Commission of Ontario, Defamation Law in the Internet Age, 95. See United Kingdom, White Paper on Online Harms, April 6, 2019, https://assets.publishing.ser vice.gov.uk/government/uploads/system/uploads/attachment_data/file/793360/On line_Harms_White_Paper.pdf.

79 Law Commission of Ontario, Defamation Law in the Internet Age, 102.

80 Law Commission of Ontario, Defamation Law in the Internet Age, 103. The Commission referenced the "right to be forgotten" regime of the European Union, Article 29 Data Protection Working Party, "Guidelines on the Implementation of the Court of Justice of the European Union Judgment on

'Google Spain and Inc v Agencia Española de Protección de Datos (AEPD) and Mario Costeja González',” November 26, 2014, C-131/12, https://ec.europa.eu/newsroom/ article29/document.cfm?action=display\&doc_id=64437. It also referenced the EU Directive on Copyright in the Digital Single Market, April 17, 2019), 2019/790, https:/ /eur-lex.europa.eu/eli/dir/2019/790/oj. 
content decisions." ${ }^{81}$ In the end the Commission took a favourable view of social media councils because: ${ }^{82}$

- A social media council would likely be able to address multi-jurisdictional dispute more effectively than a government-created [online dispute resolution] ODR tribunal;

- A social media council would operate within the contractual relationship between platforms and their users, thereby binding publishers to the process.

- Techno-legal remedies such as red-flags and the modulation of views could be directly implemented by the platform.

Nonetheless, because it judged that the subject of social media councils went beyond the scope of its mandate, Commission chose to make a recommendation only calling for the future exploration by the Ontario government of online dispute resolution, including by means of social media councils or other regulatory models. ${ }^{83}$

\section{d. Report of the Citizens' Assembly on Democratic Expression}

In 2020, the Public Policy Forum with Funding from the McConnell Foundation and the Government of Canada launched an ambitious threeyear initiative to study how to strengthen Canadian democracy in response to the ubiquitous presence of online technologies. In its first year, the goal was to develop a plan on how to mitigate the negative effects on Canadian democracy of online hate, disinformation and other forms of harmful content while encouraging the broadest possible application of the freedom of expression in Canada's Charter of Rights and Freedoms. The first year of the initiative involved two parallel and innovative processes: creating a blue-ribbon Canadian Commission on Democratic Expression, the Report of which is discussed in the next section of this article; and convening a Canadian Citizen's Assembly on Democratic Expression, made up of

81 Law Commission of Ontario, Defamation Law in the Internet Age, 103. The Commission referenced in particular the work of Article 19, The Social Media Councils: Consultation Paper, June, 2019, 7, https://www.article19.org/wp-content/uploads/2 019/06/A19-SMC-Consultation-paper-2019-v05.pdf.

82 Law Commission of Ontario, Defamation Law in the Internet Age, 104.

83 Law Commission of Ontario, Defamation Law in the Internet Age, 104 and 110. 
representative body of 42 Canadians, which authored its own Report that came out almost contemporaneously with that of the Commission. ${ }^{84}$

Over 12,000 Canadians were invited to serve in the Assembly, nearly 400 volunteered and in the end 42 were selected at random to "represent the widest possible range of voices and perspectives." 85 The Assembly was convened in March 2020 and its members met eighteen times, hearing from over a dozen experts and from senior representative of Google and Facebook. ${ }^{86}$

The Report of the Assembly contains notably a set of guiding values, ${ }^{87} \mathrm{a}$ set of key concerns, ${ }^{88}$ and 33 recommendations grouped largely around the key concerns.

The recommendations were far-reaching and served to demonstrate perhaps that informed non-experts can generate fresh proposals that at the very least provided a valuable stress test for the proposals developed in parallel by the Canadian Commission on Democratic Expression. ${ }^{89}$ Key among them were creating a new digital platforms regulator, becoming more savvy at international cooperation, establishing user ownership of personal data, introducing user-friendly standardized descriptions of terms of service across platforms, and making anonymous users accountable for their actions. ${ }^{90}$

84 Canadian Citizens' Assembly on Democratic Expression, Recommendations to Strengthen Canada's Response to New Digital Technologies and Reduce the Harm Caused by their Misuse, Public Policy Forum, January, 2021, https://ppforum.ca/wp -content/uploads/2021/01/CanadianCitizens\%E2\%80\%99AssemblyOnDemocratic Expression-PPF-JAN2021-EN.pdf.

85 Canadian Citizens' Assembly on Democratic Expression, 5. An overview of the representativeness of the Assembly is provided at 9 and the assembly process is described in detail at 22-28.

86 Canadian Citizens' Assembly on Democratic Expression, 7.

87 Canadian Citizens' Assembly on Democratic Expression, 32-33. The Assembly sought an Internet that is 1) accessible; 2) accountable; 3) reliable; 4) safe and secure; and 5) amplifies diverse voices.

88 Canadian Citizens' Assembly on Democratic Expression, 34-37. The Assembly focussed on 1) lack of oversight, transparency and accountability of digital platforms; 2) the spread of misinformation; 3) protecting digital rights and user control; and 4) harms to vulnerable persons and minority groups.

89 The Assembly presented its recommendations to the Commission in advance of the Commission issuing its Report. See Canadian Citizens' Assembly on Democratic Expression, at 28.

90 Canadian Citizens' Assembly on Democratic Expression, 37-42. 
As regards the digital platforms regulator, the Assembly wanted it to:

- develop a national code of online conduct;

- require compliance with principles of responsible algorithmic development and algorithmic transparency;

- levy fines for contravention of relevant laws and regulations;

- require independent compliance audits;

- require enhancement of content moderation policies;

- regulate the use and labelling of bots;

- establish e-courts to adjudicate complaints of harmful speech;

- regulate the collection, storage and sale of data related to underage users; and

- create mechanisms for public participation, including citizens committees.

As regards international cooperation, the Assembly urged strategic cooperation with democratic countries to establish common practices, adoption by Canada of certain existing frameworks, such as the EU GDPR, and the enhancement of collaborative competition law enforcement.

As regards user ownership of personal data, the Assembly challenged platforms inter alia:

- to grant users more control over settings influencing content, notably the option only to display content from verified users and credible sources;

- to seek consent for continued collection of data regularly with the option to download and/or fully delete all user data; and

- to delete user data when consent is not obtained or after a set period of time.

It also sought to enshrine user ownership of data in law, policies and regulations.

As regards standardized interface and descriptions of terms of service across platforms, the Assembly sought that these include clear descriptions of i) user rights, ii) information being collected and iii) how it is used and stored, as well as iv) data controls and permissions.

Finally, as regards anonymous users, the Assembly affirmed that anonymity is not a right. The Assembly sought the development of policies, laws and regulations to ensure that anonymity cannot be used to shield individuals from the consequences of producing harmful, hateful, or defamatory speech. 


\section{e. Canadian Commission on Democratic Expression}

The seven distinguished members including of the Canadian Commission on Democratic Expression included Beverley McLachlin, former Chief Justice of the Supreme Court of Canada. ${ }^{91}$ The Commission at a number of points drew explicitly upon the work of the Assembly and indeed met twice with the members of the Assembly during the course of its own deliberations. ${ }^{92}$

The Commission considered and, in the end, recommended against following either a hands-off self-regulation approach or the German NetzDG notice and takedown approach. It opted instead for a regulatory regime that would include six interconnected elements.

The first element was a new legal duty placed upon platforms to act responsibly. The virtue of this was said to be that it provides a "regulatory focus on systemic issues" rather than having regulatory intervention into thousands of content disputes. ${ }^{93}$ The idea was drawn in significant degree from the UK White Paper on Online Harms, which has proposed imposing a statutory duty of care on platforms. ${ }^{94}$ The idea was to impose on companies the onus to fulfil this legal duty, with the regulator positioned to set out how to do this in codes of practice.

However, the UK White Paper also recommended that "If companies want to fulfil these duties in a manner not set out in the codes, they will have to explain and justify to the regulator how their alternative approach will effectively deliver the same or greater level of impact." 95 It was not

91 The other members were Rick Anderson, Principal, Earnscliffe Strategy, Julie Caron-Malenfant, Director General, Institut du Nouveau Monde, Adam Dodek, Dean, Faculty of Law (Common Law Section), University of Ottawa, Amira Elghawaby, Journalist and Human Rights Advocate, Jameel Jaffer, Executive Director, Knight First Amendment Institute at Columbia University, and Jean La Rose, Former CEO, Aboriginal Peoples Television Network. See Canadian Commission of Democratic Expression, 46-47.

92 Canadian Commission of Democratic Expression, 51.

93 Canadian Commission of Democratic Expression, 31-2.

94 See United Kingdom, White Paper on Online Harms, 7. The Commission noted that " $\mathrm{t}]$ he United Kingdom, within its own legal traditions, is currently advancing a similar type of duty of care for online platforms": Canadian Commission of Democratic Expression, 31. Since Québec is not a common law jurisdiction and does not include duty of care analysis as part of the law of extra-contractual obligations, it is understandable that the Commission adopted the idea of a "duty to act responsibly," which arguably can be applied within both common law and civil law contexts.

95 See United Kingdom, White Paper on Online Harms, 7. 
made clear in Commission's Report whether platforms would be allowed to depart from codes of conduct.

It should be noted that the proposed new statutory duty gave rise to a partially dissenting minority report. Commission member Jameel Jaffer wrote: ${ }^{96}$

I find it difficult to endorse the proposed Duty to Act Responsibly when the content of that duty is left almost entirely to Parliament and the new regulator to decide. Defining the duty will require difficult tradeoffs, not only between free speech and other values-for example, privacy, equality, and due process-but also between different conceptions of free speech.

This point is particularly striking in light of Heritage Minister Steven Guilbeault's perhaps incautious public statement that "hurtful" speech could be included within the scope of what is to be regulated in an eventual bill. ${ }^{97}$

The second element in the Commission's proposed regime was a new regulator to oversee and enforce the duty to act responsibly. The goal of creating such a regulator would be to move content moderation and platform governance beyond the exclusive preserve of the platforms. "The regulator would oversee a code of conduct to guide the actions of parties under its supervision, while recognizing that not all platforms can be treated in the same manner." 98 The Commission also sought to ensure that the regulator would be able to impose significant fines and even pursue imprisonment for platform executives. ${ }^{99}$

The third element was a social media council to serve as an accessible forum in reducing harms and improving democratic expression on the internet. The social media council would be conceived as "an independent, stakeholder-based body with dedicated professional support that is attached to the regulator." 100 It would serve as a consultative body for the regulator on codes of conduct and on how changing technology, business models and user experience affect policy.

96 Canadian Commission of Democratic Expression, 48.

97 Michael Geist, "The real consequences of Steven Guilbeault's battle with the web giants," Maclean's, May 3, 2021, https://www.macleans.ca/opinion/the-real-c onsequences-of-steven-guilbeaults-battle-with-the-web-giants/.

98 Canadian Commission of Democratic Expression, 9.

99 Canadian Commission of Democratic Expression, 33.

100 Canadian Commission of Democratic Expression, 33. 
The idea of a social media council had been raised by the Law Commission of Ontario ${ }^{101}$ and could perhaps interact with online dispute resolution already being established by the platforms themselves and in some cases across platforms (such as the Global Internet Forum to Counteract Terrorism). ${ }^{102}$ A difficult question concerns how the social fractures that are evident on social platforms would be represented on the social media council. Surely it would damage the credibility of such a council to have its membership swing radically according to political winds.

The fourth element was a "world-leading transparency regime" to provide the flow of necessary information to the regulator and social media council. ${ }^{103}$ The Commission envisaged i) periodic public risk assessment reports from the platforms, ii) power granted to the regulator to compel access to information, notably to the black box of platform algorithms, iii) disclosure rules on data sharing, iv) rules on advertising transparen$\mathrm{cy}, \mathrm{v})$ public labelling and registration of bots, and vi) disclosure of the ownership structure behind those disseminating user-generated and other third-party content. ${ }^{104}$

The fifth element was an e-tribunal to facilitate and expedite dispute resolution and a process for addressing complaints swiftly and lightly before they become disputes. The key idea would be to: ${ }^{105}$

allow for the resolution of Canadian disputes within Canada. Currently, with content moderation under the control of platform companies, the training and domicile of the content moderators is a black box. Meanwhile, Facebook's new Oversight Board hears only a handful of global cases and has no Canadian member.

This was another point on which Jameel Jaffer dissented, writing: ${ }^{106}$

I am not persuaded, though, that establishing a new tribunal system with a broad mandate would be preferable to requiring large platforms themselves to establish, at their own expense, review and appeals processes that are more efficient and transparent than the ones some of them have already established. Before endorsing the proposed e-tribunals, I would want to know more about their mandate, and also

101 See supra notes 81 to 83 and accompanying discussion.

102 See Global Internet Forum to Counteract Terrorism, https:/gifct.org/.

103 Canadian Commission of Democratic Expression, 9.

104 Canadian Commission of Democratic Expression, 35-6.

105 Canadian Commission of Democratic Expression, 38.

106 Canadian Commission of Democratic Expression, 48. 
about what relationship the proposed tribunals would have to the processes that some of the platforms have already established.

The sixth element was a mechanism for quick removal of content that presents an imminent threat to a person. This would constitute an exception to the general avoidance of a notice and takedown mechanism. It would involve a "quick-response system" within 24 hours under the authority of the regulator to ensure the rapid removal- even temporarily of content that creates a reasonable apprehension of an imminent threat to the safety of the targeted party. The Commission insisted that such decisions should be subject to judicial sanction before either the e-tribunal or the courts. ${ }^{107}$

In addition to these six main recommendations, Commission also flagged a number of further issues including legal liability and fines, law enforcement resources, the interaction of the proposed regime with the Canada-US Mexico Agreement, and the need for periodic review of any legislation eventually adopted.

\section{Bill C-36}

Although Bill C-36 was not adopted by Parliament before the 2021 election, the fact that the government revealed the proposed language for amendments to the Criminal Code and to the Canadian Human Rights Act merits discussion. Should the government be re-elected, there is a strong likelihood that the bill will be reintroduced.

\section{a. Definition of hate speech and hatred}

The Taking Action to End Online Hate Report had called on the government to define hate or hatred so as to acknowledge "persons who are disproportionately targeted by hate speech including but not limited to racial, Indigenous, ethnic, linguistic, sexual orientation, gender identity, and religious groups." 108 This indeed is the approach adopted as far as defining "hate speech" for the purposes of the Canadian Human Rights Act is concerned. The bill provides that "bate speech means the content of a

107 Canadian Commission of Democratic Expression, 39.

108 House of Commons, Taking Action to End Online Hate, 41. 
communication that expresses detestation or vilification of an individual or group of individuals on the basis of a prohibited ground of discrimination." 109 It also provides that "communication does not express detestation or vilification... solely because it expresses mere dislike or disdain or it discredits, humiliates, hurts or offends."

The bill takes a somewhat different though parallel approach for the purposes of the Criminal Code, defining "hatred" as "the emotion that involves detestation or vilification and that is stronger than dislike or disdain" and specifying that "the communication of a statement does not incite or promote hatred ... solely because it discredits, humiliates, hurts or offends." 110 Since the Criminal Code already includes sanctions against inciting and promoting hatred "against any identifiable group," the Minister presumably concluded that the only purpose of a Criminal Code definition was to follow the guidance of the Supreme Court of Canada and orient the courts as to the intensity of the emotion communicated through hate propaganda. ${ }^{111}$

\section{b. Peace bond}

Bill C-36 introduces a new peace bond to help forestall hate crimes. ${ }^{112}$ Someone who reasonably fears that they could be a target of hate propaganda or criminal mischief could apply for a peace bond to be imposed on an individual to deter that person from committing the crime. Such a peace bond could involve the imposition of conditions including wearing an electronic monitoring device, a curfew, prohibition against consuming drugs or alcohol together with a requirement to provide samples for testing, a prohibition against communicating with any person, and a prohibition against possession of firearms. Surprisingly enough, no specific mention is made of prohibiting visits to or participation in online fora known to convey hate propaganda.

A breach of the proposed peace bond would carry a maximum penalty of four years' imprisonment, the same penalty that exists for breaches of other peace bonds. Consent by the appropriate Attorney General would

109 Bill C-36, s. 13.

110 Bill C-36, s. 2. This in effect codifies the approach taken by the Supreme Court of Canada in Saskatchewan (Human Rights Commission) v. Whatcott (para. 41).

111 Criminal Code, s 319.

112 Bill C-36, s. 3, adding a new s. 810.012 to the Criminal Code. 
be required before the peace bond could be used, as is the case with some existing peace bonds.

\section{c. Canadian Human Rights Act}

Rather than simply restoring the former s. 13 of the Canadian Human Rights Act, Bill C-36 includes a revised version of it. ${ }^{113}$ In addition to the new definition of "hate speech" already signalled, under the proposed legislation the Canadian Human Rights Tribunal would gain new powers 1) to order the party complained against to cease the hate speech and provide redress in consultation with the Canadian Human Rights Commission, 2) to pay damages of up to $\$ 20,000$ to each victim personally identified in the communication, and 3) to pay a fine of up to $\$ 50,000 .{ }^{114}$ The bill excludes "private communication" such as private emails or direct messages from the scope of hate speech, and does not apply to online communication service providers. Indeed, in the materials accompanying the release of the bill, the Department of Justice underscored that online platforms "are the focus of upcoming engagement by Canadian Heritage, which will outline a proposed approach to regulating social media and harmful content, including hate speech, online." 115

The bill would empower the Commission to prevent the disclosure of the identity of the complainant to the person against whom the complaint is filed, ${ }^{116}$ and gives further scope to the Tribunal to conduct confidential inquiries where there is a real and substantial risk that a complainant or witness "will be subjected to threats, intimidation or discrimination."117 Violation of such confidentiality orders made by the Commission or Tribunal would be subject to a fine of up to $\$ 50,000 .{ }^{118}$

Since it had been objected that the former s. 13 caused the Commission to flood the Tribunal with an unmanageable caseload, the bill gives stricter

113 Bill C-36, s. 13.

114 Bill C-36, s. 19.

115 Department of Justice, "Combatting hate speech and hate crimes: Proposed legislative changes to the Canadian Human Rights Act and the Criminal Code," June 23, 2021, https://www.justice.gc.ca/eng/csj-sjc/pl/chshc-lcdch/index.html.

116 Bill C-36, s. 14.

117 Bill C-36, s. 17.

118 Bill C-36, s. 20. Unlike other penal offences envisaged under the Canadian $\mathrm{Hu}$ man Rights Act, prosecution for these offences would not require prior approval of the Attorney-General of Canada, implying that prosecution should be undertaken as a matter of course. 
guidance to the Commission not to pursue cases where "the complaint indicates no hate speech." 119 The bill creates an additional caseload management tool through the possibility of awarding costs for abuse of process. ${ }^{120}$ It would also expand the Tribunal so as to address the anticipated increase in workload, adding two to five new members for a maximum of seventeen and eventually twenty members. ${ }^{121}$

\section{d. Ideas not retained}

Two ideas raised in the Minister of Justice's Consultation Paper were not retained. ${ }^{122}$ Individuals will not be empowered to pursue complaints themselves before the Tribunal and thus will rely upon the Commission to initiate complaints. Nor does Bill C-36 remove the requirement that the appropriate Attorney-General provide express consent to prosecutions for alleged wilful promotion of hatred pursuant to s. 319(2) of the Criminal Code.

\section{The Digital Citizen Initiative Consultation Papers}

The Discussion Guide and Technical Paper issued by the Digital Citizen Initiative of the Ministry of Canadian Heritage on July 26, 2021 have the appearance of internal documents drafted in preparation of legislation. It seems clear that the Minister was in the end reluctant to put forward legislation without a prior public consultation. Thus, the public now has access to the road map offered to the Minister by his civil service together with a narrow set of options presented to him. It remains to be seen whether the public consultation will raise issues and concerns going beyond the scope of the consultation documents, especially given the broader range of options canvassed in the various reports discussed above.

The Discussion Guide is meant to background and justification for the Technical Paper and uses lay language. The Technical Paper has the same structure as the Discussion Paper but uses formulations that could

119 Bill C-36, s. 15.

120 Bill, C-36, s.19.

121 Bill C-36, s. 16.

122 Minister of Justice and Attorney General of Canada, Consultation Paper: Online Hate, July 14, 2020. https://ocla.ca/wp-content/uploads/2020/07/2020-07-14-Cons ultation-paper-Online-hate.pdf. 
find their way into legislation. This summary focuses primarily on the Technical Paper.

The Technical Paper is divided into two "Modules" that could presumably become two parts of the legislative framework: 1) a new legislative and regulatory framework for social media platforms; and 2) modifications to existing legislation. Not surprisingly, Module 1 is the more elaborate and is itself divided into four parts: A) a general framework of purposes, interpretation and application; B) new rules and obligations; C) new regulators; and D) new regulatory powers and enforcement mechanisms.

Module 1(A) puts forward a set of "premises" about the benefits and potentially harmful impacts of "Online Communication Services" (OCSs). ${ }^{123}$ An OCS is defined as "a service that is accessible to persons in Canada, the primary purpose of which is to enable users of the service to communicate with other users of the service, over the internet," but would "exclude services that enable persons to engage only in private communications." 124 The Discussion Paper explains that the definition "is intended to capture major platforms, (e.g., Facebook, Instagram, Twitter, YouTube, TikTok, Pornhub), and exclude products and services that would not qualify as online communication services, such as fitness applications or travel review websites." 125 Nonetheless, it would appear that "private" communication services owned by major platforms, such as Facebook's WhatsApp, and which can be used to spread harmful content, are prima facie to be excluded from the application of the legislation. The proposed legislation would give power to the cabinet, upon consultation with the new Digital Safety Commissioner described below, to narrow or extend the definition of OCS by regulation. The legislation would apply to OCSs and to "the closest legal entity to a regulated OCS", called an Online Communication Service Provider (OCSP). ${ }^{126}$

123 Digital Citizen Initiative, “Technical Paper,” Module 1, para. 1.

124 Digital Citizen Initiative, "Technical Paper," Module 1, para. 2.

125 Digital Citizen Initiative, "Discussion Guide," "Who and what would be regulated".

126 Digital Citizen Initiative, “Technical Paper,” Module 1, para. 6. 
The legislation would concern "harmful content" falling into five defined categories: ${ }^{127}$

- child sexual exploitation, 1 ) as specified in the Criminal Code, including child pornography, and 2) material related to child sexual exploitation ("e.g., screen shots of videos that do not include the criminal activity but refer to it obliquely; up-to-date photos of adults who were exploited/ abused as children being posted in the context of their exploitation and abuse as children");

- terrorist content "that actively encourages terrorism and which is likely to result in terrorism";

- content that incites violence, namely "that actively encourages or threatens violence and which is likely to result in violence";

- hate speech as defined in Bill C-36 and "communicated in a context in which it is likely to cause harms identified by the Supreme Court of Canada and in a manner identified by the Court in its hate speech jurisprudence"; and

- non-consensual sharing of intimate images as defined in the Criminal Code "with the intent to capture the communication of an intimate image of a person that the person depicted in the image or video did not give their consent to distributing, or for which it is not possible to assess if a consent to the distribution was given by the person depicted in the image or video."

It would thus not extend to defamatory speech. Nor would it extend to misinformation or other "awful but lawful" content.

Module 1(B) proposes creating a new obligation that "an OCSP must take all reasonable measures, which can include the use of automated systems, to identify harmful content that is communicated on its OCS and that is accessible to persons in Canada." 128 It thus comes close to the duty to act responsibly proposed by the Canadian Commission on Democratic Expression. The obligation would extend to abiding by regulations prescribed by the Digital Safety Commissioner and would also require that OCSPs ensure that the measures they take not give rise to differential treatment of any group based on a prohibited ground of discrimination.

Furthermore, "an OCSP must address all content that is flagged by any person in Canada as harmful content" within 24 hours. ${ }^{129}$ This means

127 Digital Citizen Initiative, “Technical Paper," Module 1, para. 8.

128 Digital Citizen Initiative, “Technical Paper,” Module 1, para. 10.

129 Digital Citizen Initiative, “Technical Paper,” Module 1, para. 11. 
either responding to that person that the content does not meet the definition of harmful content or taking down the content. Thus, in this respect the proposed approach follows the NetzDG model despite the recommendation of the Canadian Commission on Democratic Expression not to do so.

Module 1(B) also includes significant transparency and procedural requirements for OCSPs. ${ }^{130}$ The flagging mechanism must be "accessible and easy-to-use," as must be the opportunity to make representations and compel prompt review and reconsideration by the OCSP. Upon reconsideration, notice must be given of the recourse to the new Digital Recourse Council of Canada, discussed below. The OCSP must publish "clear content-moderation guidelines," and "must generate and provide reports on a scheduled basis to the Digital Safety Commissioner [also discussed below] on Canada-specific data." The content of these latter reports is to be prescribed in significant detail, including, for example, information from the OCSPs about "how they monetize harmful content". Regulations are envisaged to determine what records OCSPs must keep.

The Technical Paper leaves open two options as to how OCSPs should meet a mandatory notification requirement for law enforcement agencies. The options involve differing thresholds of potential harm. Option (a) would require notification to the Royal Canadian Mounted Police where the OCSP has reasonable grounds to believe that defined "harmful content reflects an imminent risk of serious harm to any person or to property." Option (b) would set the notification requirements by regulation. As the Discussion guide notes: "The legal thresholds (reasonable suspicion, reasonable grounds to believe) for reporting this content... could differ based on the category. For example, the threshold for reporting potentially terrorist and violent extremist content could be lower than that for potentially criminal hate speech." ${ }^{31}$ Option (b) would include mandatory reporting of potential terrorist activity to the Canadian Security Intelligence Service. At stake is that police forces are seeking to require platforms to inform them when they take down illegal content and to provide the deleted content to the police as evidence for possible further criminal investigation. The RCMP seeks to hold these materials in a database. Other government partners are resisting this approach, although apparently all stakeholders agree with requiring the platforms to keep the content they

130 Digital Citizen Initiative, “Technical Paper,” Module 1, paras. 12-15.

131 Digital Citizen Initiative, "Discussion Guide," "Engaging law enforcement and CSIS". 
remove for a year. Option (a) is a compromise position involving narrower disclosure.

Module $1(\mathrm{C})$ proposes the establishment of four new bodies: the Digital Safety Commissioner, the Digital Recourse Council of Canada, an Advisory Board and the Digital Safety Commission. The Commissioner would handle the basic administration of the new legislation, including giving general advice to OCSPs (though not about specific content-moderation decisions), ${ }^{132}$ establishing an Incident Response Protocol for potential terrorist activity, ${ }^{133}$ receive complaints from the public about OCSP non-compliance, ${ }^{134}$ and have the power to issue regulations, ${ }^{135}$ subject to binding directions from cabinet. ${ }^{136}$

The Digital Recourse Council of Canada would be designed to provide an independent recourse in response to OCSP decisions and would arise only upon exhaustion of remedies available with the OCSP. It is not entirely clear how this would interact, say, with the Facebook Oversight Board, which does not necessarily provide a timely remedy. It is not made entirely clear whether this body would operate as an eCourt. Compliance orders issued by the Digital Safety Commissioner would be appealed to the Personal Information and Data Protection Tribunal created under the proposed overhaul of data privacy legislation. ${ }^{137}$

The Commissioner and Council would be counselled by a new, external Advisory Board having the characteristics of the recommended social media council. ${ }^{138}$ Its members would be drawn from civil society, academia, and cultural groups. Its role would be to inform the Council and the Commissioner, both of which would be appointed by the government but independent from ministerial oversight.

The Commissioner, Council and Advisory Board would all operate supported by an umbrella Digital Safety Commission of Canada, which would have a Chief Executive Officer who is not the Commissioner. ${ }^{139}$ The entire

132 Digital Citizen Initiative, “Technical Paper,” Module 1, para. 16.

133 Digital Citizen Initiative, “Technical Paper,” Module 1, paras. 18-19.

134 Digital Citizen Initiative, “Technical Paper,” Module 1, paras. 40-44.

135 Digital Citizen Initiative, “Technical Paper,” Module 1, para. 17.

136 Digital Citizen Initiative, “Technical Paper,” Module 1, para. 39.

137 See Bill C-11. See also Digital Citizen Initiative, "Technical Paper," Module 1, para. 81.

138 See Digital Citizen Initiative, “Technical Paper,” Module 1, paras. 71-75.

139 See Digital Citizen Initiative, "Technical Paper,” Module 1, paras. 60-65. 
apparatus would operate on a cost-recovery basis through charges imposed on the OCSPs. ${ }^{140}$

Module 1(D) proposes a new set of powers and enforcement remedies, including compliance orders against OCSPs and broad inspection powers for the Commissioner, and Administrative Monetary Penalties for non-compliance issued by the Personal Information and Data Protection Tribunal. ${ }^{141}$ It would also be an offence for an OCSP to fail to comply with a compliance agreement, adhere to an order issued by the Council or Commissioner, resist or obstruct and inspection, or knowingly make false or misleading statements to the Commissioner or Council. ${ }^{142}$ For the most serious offences, the maximum penalty would be a fine not exceeding five percent of gross global revenues in the financial year that precedes the date of sentencing or $\$ 25,000,000$, whichever is higher. If an OCSP "repeatedly demonstrates persistent non-compliance" with respect to orders for removing content relating to child sexual exploitation or terrorism, the Commissioner could apply to the Federal Court for an order requiring telecommunications service providers to block access to the offending OCS in Canada. ${ }^{143}$

Module 2 proposes certain amendments to existing Canadian legislation. As regards child pornography, the Mandatory Reporting Act ${ }^{144}$ would be amended so as to extend its application to OCSPs and other internet services, centralize reporting with the National Child Exploitation Crime Centre of the Royal Canadian Mounted Police (RCMP) and generally strengthen its administration. ${ }^{145}$ An unresolved issue concerning the reporting of clear child pornography offences has to do with transmission data (i.e., Internet protocol address, date, time, type, origin, destination of the material) or basic subscriber information (BSI) (i.e., customer's name, address, phone number, billing information associated with the IP address). One option is simply to require that such information be shared with the police. The other, stricter, option would require the police to seek

140 See Digital Citizen Initiative, “Technical Paper,” Module 1, paras. 66-70.

141 See Digital Citizen Initiative, “Technical Paper,” Module 1, paras. 81-82, 88-114.

142 See Digital Citizen Initiative, "Technical Paper," Module 1, paras. 119.

143 See Digital Citizen Initiative, "Technical Paper," Module 1, paras. 120.

144 An Act respecting the mandatory reporting of Internet child pornography by persons who provide an Internet service 2011, S.C. c. 4.

145 See Digital Citizen Initiative, “Technical Paper,” Module 2, Mandatory Reporting Act, paras. 1-11. 
a production order from the court to obtain BSI. ${ }^{146}$ A parallel option being considered is to allow the Canadian Security Information Service easier access to BSI in the case of terrorist content, since currently CSIS must seek a warrant, a process that can take four to six months. ${ }^{147}$

\section{Final critical observations}

In my concluding remarks, I would like to signal what I believe are two important conceptual challenges raised by the emerging Canadian approach. The first of these was signalled by Jameel Jaffe in his dissenting report to the Commission. ${ }^{148}$ How should a national regulatory approach properly interconnect with the emerging online dispute resolution regimes developed by platforms themselves, notably the Facebook Oversight Board? The second challenge was signalled by the Commission when quoting Prof. Taylor Owen to the effect that the negative effects of social media companies are "baked into their business models." 149 How can regulators retool business models that rely on algorithms that amplify the propagation of extreme content as well on the sweeping collection of personal data that allows platforms to target users with recommended, sometimes extreme, content?

Let me make some affirmations designed to provoke debate. The establishment of the Facebook Oversight Board gives rise to the counter-intuitive conclusion that national regulatory responses should seek to strengthen and widen the reach of online dispute resolution offered by platforms regime rather than simply to substitute for it. ${ }^{150} \mathrm{I}$ take the point that as of August 19, 2021 the Oversight Board had only rendered fifteen decisions in its inaugural year. But in addition to the much-discussed decision on Donald Trump, ${ }^{151}$ the Zwarte Piet decision handed down on April 13, 2021 by the Oversight Board illustrates that a transnational body perhaps

146 See Digital Citizen Initiative, “Technical Paper," Module 2, Mandatory Reporting Act, paras. 7-8.

147 See Digital Citizen Initiative, “Technical Paper," Module 2, Canadian Security Intelligence Service Act, paras. 1-6.

148 Canadian Commission of Democratic Expression, 48.

149 Canadian Commission of Democratic Expression, 12.

150 See a detailed discussion of the Facebook Oversight Board in chapter 1.6. of this volume (Schultz, Mårten: Six Problems with Facebook’s Oversight Board).

151 Facebook Oversight Board, Case decision 2021-001-FB-FBR, https://oversightboa rd.com/decision/FB-691QAMHJ/. 
can accomplish something important that a national regulator might be less capable of achieving. ${ }^{152}$ That case concerned the removal of a 17 second video showing a child meeting three adults, one dressed to portray "Sinterklaas" (the Dutch version of Santa Claus) and two portraying "Zwarte Piet," also referred to as "Black Pete," who in the Dutch Christmas tradition accompanies Sinterklaas during the Feast of Saint Nicholas, distributing sweets. The video in question was posted to document this event. The two adults portraying Zwarte Piet had their faces painted black, wore Afro wigs under hats and colourful renaissance-style clothes. All the adults and the child in the video appeared to be white, including those with their faces painted black. The Board conducted a sophisticated analysis grounded notably in the UN Guiding Principles on Business and Human Rights and in human rights standards including Article 19 of the International Covenant on Civil and Political Rights. It considered the Zwarte Piet "tradition" in a comparative perspective and noted that it could be practiced without blackface or racial stereotypes. The majority upheld the removal of the content but concluded that Facebook had not sufficiently notified users about its community standard.

The point is that a purely Dutch body may or may not have been willing to put the Dutch tradition in comparative context and to consider the matter from the vantage point of how the stereotypes depicted were to be perceived in the context of global communications. Consequently, I would suggest that Canada consider the following points in addition to the direction being apparently being considered:

1) Promulgate a standard promoting the establishment of internal appeal bodies parallel to the Oversight Board for other OCSPs;

2) Promulgate a standard ensuring balanced membership in the instances established for content moderation and reconsideration processes at the OCSP level and promoting a role for Canada and other members of the Freedom Online Coalition in ensuring the representativeness, expertise and commitment to online freedom of OCSP online dispute settlement bodies as a whole ${ }^{153}$;

3) Ensure coordination and consultation between the new Council and "appellate" online dispute settlement bodies such as the Oversight Board; and

152 Facebook Oversight Board, Case decision 2021-002-FB-UA, https://oversightboar d.com/decision/FB-S6NRTDAJ/.

153 See Freedom Online Coalition, https:/freedomonlinecoalition.com/. 
4) Promulgate a standard promoting whistleblower access to "appellate" online dispute settlement bodies such as the Oversight Board. Facebook moderators have often been highly dissatisfied with the internal implementation of Facebook community standards and have encountered heavy-handed control from senior management. ${ }^{154}$ One thinks as well of the controversy around the Google AI Ethics Unit. ${ }^{155}$ Internal dissent at the platforms on these issues should be harnessed and subject to independent oversight.

The largest challenge to producing an online speech environment conducive to democratic expression is surely the need to adjust the underlying business models of the platforms. How does regulation get to the algorithmic ghost inside the machine? Here I have only more speculative ideas to offer, but ones that show some signs of promise. First, a duty to "take all reasonable measures to identify harmful content," conjoined with the fiduciary duty that companies owe to shareholders and stakeholders, could give rise to pressure on business models, notably as advertisers also attract scrutiny for having their messages accompany hateful content. Second, as discussed earlier, ${ }^{156}$ the adoption of a more robust privacy regime with powers given to the Privacy Commissioner to constrain the collection of personal information, if acted upon together with other like-minded jurisdictions, could have significant impact on the business case of some platforms. Indeed, one is already seeing the impact of Apple's new privacy drive on Facebook's advertising relationships. ${ }^{157}$ Third, and somewhat more ambitiously, perhaps a group of like-minded states could adopt legislation akin to the proposed Protecting Americans from Dangerous Algorithms Act designed to hold platforms liable for algorithms designed to amplify extreme content. ${ }^{158}$ Finally, and most ambitiously of all, momentum could

154 Andrew Marantz, "Why Facebook Can't Fix Itself," New Yorker, October 12, 2020, https://www.newyorker.com/magazine/2020/10/19/why-facebook-cant-fix-i tself.

155 Shirin Ghaffary, "Google says it's committed to ethical AI research. Its ethical AI team isn't so sure," Vox, June 2, 2021, https://www.vox.com/recode/22465301/go ogle-ethical-ai-timnit-gebru-research-alex-hanna-jeff-dean-marian-croak.

156 See supra note 32 to 36 and accompanying discussion.

157 Laura Forman, "Facebook and Its Advertisers Feel Pinch of Apple's Privacy Drive," Wall Street Journal, June 12, 2021, https:/www.wsj.com/articles/facebook -and-its-advertisers-feel-pinch-of-apples-privacy-drive-11623502980.

158 U.S. Congress, House, Protecting Americans from Dangerous Algorithms Act, H.R. 8636 116th Congress 2d Session, introduced in House October 20, 2020, https:/ /www.congress.gov/bill/116th-congress/house-bill/8636/text. See also Tom Malinowski, "Reps. Malinowski and Eshoo Reintroduce Bill to Hold Tech Platforms 
gather among leading jurisdictions to overhaul competition law so as to make it easier to break up platforms and reshape the way they operate. ${ }^{159}$

\section{Bibliography}

Anti-Terrorism Act of 2015. Statutes of Canada. 2015, c. 20. https://laws-lois.justice.gc. ca/eng/annualstatutes/2015_20/page-3.html\#h-20.

Arnold, Brent. "Online Harms: Federal Government Announces New Rules and Regulator.” Gowlings WLG, March 31, 2021. https:/gowlingwlg.com/en/insights -resources/articles/2021/federal-government-announces-new-rules/.

Article 19. The Social Media Councils: Consultation Paper. June, 2019. https://www.ar ticle19.org/wp-content/uploads/2019/06/A19-SMC-Consultation-paper-2019-v05. pdf.

An Act respecting the mandatory reporting of Internet child pornography by persons who provide an Internet service. 2011, S.C. c. 4.

Bill C-10. An Act to amend the Broadcasting Act and to make related and consequential amendments to other Acts, 2d sess., 43d Parliament, November 3, 2020. https://par l.ca/DocumentViewer/en/43-2/bill/C-10/first-reading\#ID0E02B0AA.

Bill C-11. Digital Charter Implementation Act, 2020, 2d sess., 43d Parliament, November 17, 2020. https://parl.ca/DocumentViewer/en/43-2/bill/C-11/first -reading.

Bill C-36. An Act to amend the Criminal Code and the Canadian Human Rights Act and to make related amendments to another Act (hate propaganda, hate crimes and hate speech), 2d sess., 43d Parliament, June 23, 2021. https:/www.parl.ca/LegisIn fo/BillDetails.aspx?Bill=C36\&Language=E\&Mode=1\&Parl=43\&Ses=2 .

Broadcasting and Telecommunications Legislative Review Panel. Final Report. Canada's communications future: Time to act. January, 2020. https://www.ic.gc.ca/ eic/site/110.nsf/vwapj/BTLR_Eng-V3.pdf/\$file/BTLR_Eng-V3.pdf.

Broadcasting Distribution Regulations. SOR/97-555. https://laws.justice.gc.ca/eng/reg ulations/SOR-97-555/page-3.html\#h-1010707.

Burt, Andrew. "Can Facebook Ever be Fixed?" Harvard Business Review. April 8, 2019, https://hbr.org/2019/04/can-facebook-ever-be-fixed.

California Code. Title 1.81.5. California Consumer Privacy Act of 2018. https://leginfo. legislature.ca.gov/faces/codes_displayText.xhtml?division=3.\&part=4.\&lawCode $=$ CIV\&title $=1.81 .5$.

Accountable for Algorithmic Promotion of Extremism” March 24, 2021, https:// malinowski.house.gov/media/press-releases/reps-malinowski-and-eshoo-reintrod uce-bill-hold-tech-platforms-accountable.

159 Cecilia Kang, "Lawmakers, Taking Aim at Big Tech, Push Sweeping Overhaul of Antitrust," New York Times, June 11, 2020, https://www.nytimes.com/2021/06/11 /technology/big-tech-antitrust-bills.html. 
Canada-U.S.-Mexico Trade Agreement. Article 19.17. https:/www.international.gc.ca/ trade-commerce/trade-agreements-accords-commerciaux/agr-acc/cusma-aceum/te xt-texte/19.aspx?lang=eng.

Canadian Citizens' Assembly on Democratic Expression. Recommendations to Strengthen Canada's Response to New Digital Technologies and Reduce the Harm Caused by their Misuse. Public Policy Forum, January, 2021. https://ppforum.ca/ wp-content/uploads/2021/01/CanadianCitizens\%E2\%80\%99AssemblyOnDemoc raticExpression-PPF-JAN2021-EN.pdf.

Canadian Commission of Democratic Expression. Harms Reduction: A Six-Step Program to Protect Democratic Expression Online. Public Policy Forum. January, 2021. https://ppforum.ca/wp-content/uploads/2021/01/CanadianCommissionOnDem ocraticExpression-PPF-JAN2021-EN.pdf.

Canadian Human Rights Act. Revised Statutes of Canada. 1985, c. H-6, archived version. https://laws-lois.justice.gc.ca/eng/acts/h-6/section-13-20021231.html\#: : text=13\%20(1)\%20It\%20is\%20a,Parliament $\% 2 \mathrm{C} \% 20$ any $\% 20$ matter\%20that $\% 20$ is.

Canadian Human Rights Commission. "Statement - We must do more to curb online hate.” January 21, 2021. https://www.chrc-ccdp.gc.ca/en/resources/statem ent-we-must-do-more-curb-online-hate.

Canadian Race Relations Foundation. "Poll demonstrates support for strong social media regulations to prevent online hate and racism.” January 25, 2021. https:// www.crrf-fcrr.ca/en/news-a-events/media-releases/item/27349-poll-demonstrates -support-for-strong-social-media-regulations-to-prevent-online-hate-and-racism.

Canadian Radio-television and Telecommunications Commission (CRTC). "Frequently asked questions.” April 1, 2015. https://crtc.gc.ca/eng/faqs.htm.

Christchurch Call to Eliminate Terrorist and other Extremist Content Online. May 15, 2019. https://www.christchurchcall.com/call.html.

Commission des droits de la personne et des droits de la jeunesse. Mémoire à la Commission des institutions de l'Assemblée nationale. August 2015. https://www.cd pdj.qc.ca/storage/app/media/publications/memoire_PL59_discours-haineux.pdf.

Les actes haineux à caractère xénophobe, notamment islamophobe: résultats d'une recherche menée à travers le Québec, August, 2019. https://www.cdpdj.qc.ca/sto rage/app/media/publications/etude_actes_haineux.pdf.

Commission des droits de la personne et des droits de la jeunesse (Coffy et une autre) c. Brisson. 2009 QCTDP. https://canlii.ca/t/22qhm.

Copyright Act. Revised Statutes of Canada. 1985, c. C-42. https://laws-lois.justice.gc.ca leng/acts/c-42/.

Criminal Code. Revised Statutes of Canada. 1985, c. C-46. https://laws-lois.justice.gc.c a/eng/acts/c-46/.

Curry, Bill and Raman-Wilms, Menaka. "New internet bill on hate crime and revenge porn coming in 'very near future,' Guilbeault says." Globe \& Mail, June 7, 2021. https:/www.theglobeandmail.com/politics/article-new-internet-bill-on -hate-crime-and-revenge-porn-coming-in-very-near/. 
Davey, Jacob, Mackenzie Hart, Cécile Guerin, ed. Jonathan Birdwell. Interim Report: An Online Environmental Scan of Right-wing Extremism in Canada, The Institute for Strategic Dialogue. June 19, 2020. https://www.isdglobal.org/wp-c ontent/uploads/2020/06/An-Online-Environmental-Scan-of-Right-wing-Extremis m-in-Canada-ISD.pdf.

Department of Justice. "Combatting hate speech and hate crimes: Proposed legislative changes to the Canadian Human Rights Act and the Criminal Code." June 23, 2021. https://www.justice.gc.ca/eng/csj-sjc/pl/chshc-lcdch/index.html.

Digital Citizen Initiative, Department of Canadian Heritage. "Discussion Guide." July 26, 2021. https://www.canada.ca/en/canadian-heritage/campaigns/harmful-o nline-content/discussion-guide.html.

“Technical Paper.” July 26, 2021. https:/www.canada.ca/en/canadian-heritage/cam paigns/harmful-online-content/technical-paper.html.

Edelman, Gilad. “Social Media CEOs Can't Defend Their Business Model.” Wired, March 25, 2021. https:/www.wired.com/story/social-media-ceo-hearing-cant-def end-business-model/.

Elghawaby, Amira. "Canada is Bringing in New Legislation to Stop the Spread of Online Hate. Here's How It Can Work.” Press Progress, April 7, 2021. https://pres sprogress.ca/canada-is-bringing-in-new-legislation-to-stop-the-spread-of-online-ha te-heres-how-it-can-work/.

Eliadis, Pearl. “The Controversy Entrepreneurs.” Maisonneuve, August 20, 2009. https:/maisonneuve.org/article/2009/08/20/controversy-entrepreneurs/.

European Union. Article 29 Data Protection Working Party. "Guidelines on the Implementation of the Court of Justice of the European Union Judgment on 'Google Spain and Inc v Agencia Española de Protección de Datos (AEPD) and Mario Costeja González'.” November 26, 2014, C-131/12. https://ec.europa.eu/newsroo $\mathrm{m} /$ article29/document.cfm?action=display\&doc_id=64437.

Directive on Copyright in the Digital Single Market. April 17, 2019), 2019/790. https:// eur-lex.europa.eu/eli/dir/2019/790/oj.

Facebook Oversight Board. https://oversightboard.com/.

Case decision 2021-001-FB-FBR. https://oversightboard.com/decision/FB-691QAM $\mathrm{HJ} /$.

Case decision 2021-002-FB-UA. https://oversightboard.com/decision/FB-S6NRTDA $\mathrm{J} /$.

Forman, Laura. "Facebook and Its Advertisers Feel Pinch of Apple's Privacy Drive." Wall Street Journal, June 12, 2021. https:/www.wsj.com/articles/facebook-and-its -advertisers-feel-pinch-of-apples-privacy-drive-11623502980.

Freedom Online Coalition. https://freedomonlinecoalition.com/

Ghaffary, Shirin. "Google says it's committed to ethical AI research. Its ethical AI team isn't so sure.” Vox, June 2, 2021. https://www.vox.com/recode/22465301/go ogle-ethical-ai-timnit-gebru-research-alex-hanna-jeff-dean-marian-croak.

Geist, Michael. "The real consequences of Steven Guilbeault's battle with the web giants." Maclean's, May 3, 2021. https:/www.macleans.ca/opinion/the-real-conse quences-of-steven-guilbeaults-battle-with-the-web-giants/. 
Germany. Network Enforcement Act, English translation. https://www.bmjv.de/Share dDocs/Gesetzgebungsverfahren/Dokumente/NetzDG_engl.pdf?_blob=publicat ionFile\&v=2.

Gill, Lex. "Legal Aspects of Hate Speech." Canadian Commission on Democratic Expression, June, 2020. https://ppforum.ca/wp-content/uploads/2020/07/1.DemX _LegalAspects-EN.pdf.

Global Internet Forum to Counteract Terrorism. https://gifct.org/.

Hill, Kashmir and Daisuke Wakabayashi. "Google Seeks to Break Vicious Cycle of Online Slander.” New York Times, June 10, 2021. https:/www.nytimes.com/2021 /06/10/technology/google-algorithm-known-victims.html.

House of Commons. Standing Committee on Justice and Human Rights. Taking Action to End Online Hate. June, 2019. https:/www.ourcommons.ca/Content/Co mmittee/421/JUST/Reports/RP10581008/justrp29/justrp29-e.pdf.

Standing Committee on Access to Information, Privacy and Ethics. Democracy under Threat: Risks and Solutions in the Era of Disinformation and Data Monopoly. December, 2018. https:/www.ourcommons.ca/Content/Committee/421/ETHI/ Reports/RP10242267/ethirp17/ethirp17-e.pdf

Jaworski, Michal and Athar Malik. "Did You Notice? When A Notice Is Not A Notice Under The Notice And Notice Regime.” March 27, 2019. https:/www.m ondaq.com/canada/copyright/792094/did-you-notice-when-a-notice-is-not-a-notic e-under-the-notice-and-notice-regime.

Kang, Cecilia. "Lawmakers, Taking Aim at Big Tech, Push Sweeping Overhaul of Antitrust.” New York Times, June 11, 2020. https:/www.nytimes.com/2021/06/11 /technology/big-tech-antitrust-bills.html.

Karadeglija, Anja. "New definition of hate to be included in Liberal bill that might also revive contentious hate speech law." National Post, March 3, 2021. https://na tionalpost.com/news/politics/new-definition-of-hate-to-be-included-in-liberal-bill -that-might-also-revive-contentious-hate-speech-law.

Kilvington, Daniel. "The virtual stages of hate: Using Goffman's work to conceptualise the motivations for online hate." Media, Culture \& Society 43, no. 2 (2020): 256-272. https://journals.sagepub.com/doi/10.1177/0163443720972318.

Krishnamurthy, Vivek and Jessica Fjeld. "CDA 230 Goes North American? Examining the Impacts of the USMCA's Intermediary Liability Provisions in Canada and the United States." SSRN, July 7, 2020. https://ssrn.com/abstract=3645462.

Krolik Adam, and Kashmir Gill. "The Slander Industry.” New York Times, April 24, 2021. https://www.nytimes.com/interactive/2021/04/24/technology/online-sland er-websites.html.

Law Commission of Ontario. Defamation Law in the Internet Age, March 2020 at 1. https://www.lco-cdo.org/wp-content/uploads/2020/03/Defamation-Final-Report -Eng-FINAL-1.pdf.

"Learn about us." https://www.lco-cdo.org/en/learn-about-us/.

Lemire v. Canada (Human Rights Commission). 2014 FCA 18. https://canlii.ca/t/g2x2 d. 
Madison, James. Federalist No.10, in The Federalist Papers. ed. Clinton Rossiter (New York: New American Library, 1961). https://avalon.law.yale.edu/18th_cen tury/fed10.asp.

"Notes for the National Gazette Essays." (ca. December 19, 1791-March 3, 1792). https://founders.archives.gov/?q=literati\%20\%22useful\%20knowledge $\% 22 \&$ s=11 $11311111 \& \mathrm{r}=1$.

"Report on the Virginia Resolutions.” January, 1800. https://press-pubs.uchicago.ed u/founders/documents/amendI_speechs24.html.

Marantz, Andrew. "Why Facebook Can't Fix Itself.” New Yorker. October 12, 2020. https:/www.newyorker.com/magazine/2020/10/19/why-facebook-cant-fix-itself.

Malinowski, Tom. "Reps. Malinowski and Eshoo Reintroduce Bill to Hold Tech Platforms Accountable for Algorithmic Promotion of Extremism.” March 24, 2021. https://malinowski.house.gov/media/press-releases/reps-malinowski-and-es hoo-reintroduce-bill-hold-tech-platforms-accountable.

Minister of Justice and Attorney General of Canada. Consultation Paper: Online Hate. July 14, 2020. https://ocla.ca/wp-content/uploads/2020/07/2020-07-14-Cons ultation-paper-Online-hate.pdf.

Office of the Prime Minister of Canada. "Canada joins Christchurch Call to Action to eliminate terrorist and violent extremist content online.” May 15, 2019. https://pm.gc.ca/en/news/news-releases/2019/05/15/canada-joins-christchurch-cal l-action-eliminate-terrorist-and-violent.

“Minister of Canadian Heritage Mandate Letter.” December 13, 2019. https://pm.g c.ca/en/mandate-letters/2019/12/13/minister-canadian-heritage-mandate-letter.

"Minister of Justice and Attorney General of Canada Mandate Letter." December 13, 2019. https://pm.gc.ca/en/mandate-letters/2019/12/13/minister-justice-and-att orney-general-canada-mandate-letter.

“Minister of Canadian Heritage Supplementary Mandate Letter.” January 15, 2021. https://pm.gc.ca/en/mandate-letters/2021/01/15/minister-canadian-heritage-suppl ementary-mandate-letter.

"Minister of Justice and Attorney General of Canada Supplementary Mandate Letter.” January 15, 2021. https://pm.gc.ca/en/mandate-letters/2021/01/15/minist er-justice-and-attorney-general-canada-supplementary-mandate.

Office of the Privacy Commissioner of Canada. "A Data Privacy Day Conversation with Canada's Privacy Commissioner.” January 28, 2020. https://www.priv.gc.ca /en/opc-news/speeches/2020/sp-d_20200128/.

Paliser, Eli. The filter bubble: what the Internet is hiding from you, (New York: Penguin, 2011).

Projet de loi 59. Loi édictant la Loi concernant la prévention et la lutte contre les discours haineux et les discours incitant à la violence et apportant diverses modifications législatives pour renforcer la protection des personnes, $1^{\mathrm{er}}$ sess., $41^{\mathrm{e}}$ législature, June 10, 2015. http://m.assnat.qc.ca/fr/travaux-parlementaires/projets-loi/projet-loi-59 $-41-1 . h t m l$. 
Projet de loi 64. Loi modernisant des dispositions législatives en matière de protection des renseignements personnels $1^{\mathrm{er}}$ sess., $42^{\mathrm{e}}$ legislature, June 12 , 2020. http://m.assnat.q c.ca/fr/travaux-parlementaires/projets-loi/projet-loi-64-42-1.html.

Protecting Canadians from Online Crime Act. Statutes of Canada, 2014, c. 31. https://la ws-lois.justice.gc.ca/eng/annualstatutes/2014_31/FullText.html.

$R v$ Keegstra. [1990] 3 SCR 697. https://scc-csc.lexum.com/scc-csc/scc-csc/en/item/69 5/index.do.

Rosen, Jeffrey. “America is Living James Madison's Nightmare.” The Atlantic, October, 2018. https:/www.theatlantic.com/magazine/archive/2018/10/james-madiso n-mob-rule/568351/.

Saskatchewan (Human Rights Commission) v. Whatcott. [2013] 1 SCR 467. https://scc -csc.lexum.com/scc-csc/scc-csc/en/item/12876/index.do?q=whatcott.

Sentelle David. "Freedom of the Press: A Liberty for All or a Privilege for a Few?" Cato Supreme Court Review (2014): 15-34.

Sheehan, Colleen. "The Politics of Public Opinion: James Madison's 'Notes on Government'.” William and Mary Quarterly 49, no. 4 (1992) 609-27.

Solomun, Sonja Maryna Polataiko, and Helen A. Hayes. "Platform Responsibility and Regulation in Canada: Considerations on Transparency, Legislative Clarity, and Design.” Harvard Journal of Law and Technology (Digest)) 34 (2021): 1-18. https://jolt.law.harvard.edu/digest/platform-responsibility-and-regulation-in-can ada-considerations-on-transparency-legislative-clarity-and-design.

Swartz, Jon. "California's landmark privacy law is Facebook's next 'nightmare'." Market Watch, August 22, 2020. https://www.marketwatch.com/story/californias -landmark-privacy-law-is-facebooks-next-nightmare-2020-08-18.

Thompson, Elizabeth. "Canada not exempt from social media forces that created U.S. Capitol riot, heritage minister says.” CBC News, January 29, 2021. https://w ww.cbc.ca/news/politics/facebook-twitter-canada-regulation-1.5894301.

Tusikov, Natasha. "U.K. and Australia move to regulate online hate speech, but Canada lags behind.” National Post, April 11, 2019. https://nationalpost.com/pm n/news-pmn/u-k-and-australia-move-to-regulate-online-hate-speech-but-canada-la gs-behind.

Chokepoints: Global Private Regulation on the Internet, (Oakland: University of California Press, 2017).

United Kingdom. White Paper on Online Harms. April 6, 2019. https://assets.publi shing.service.gov.uk/government/uploads/system/uploads/attachment_data/file/ 793360/Online_Harms_White_Paper.pdf.

Urban, Jennifer M., Joe Karaganis and Brianna L. Schofield. "Notice and Takedown in Everyday Practice" UC Berkeley Public Law Research Paper, No. 2755628, March 24, 2017, https://papers.ssrn.com/sol3/papers.cfm?abstract_id=2755628.

U.S. Congress. House. Protecting Americans from Dangerous Algorithms Act, H.R. 8636 116th Cong., 2d sess. Introduced in House October 20, 2020. https://www. congress.gov/bill/116th-congress/house-bill/8636/text.

U.S. Communications Decency Act. U.S. Code 47 (2018). 
Webe, Joel. "Hate speech no longer part of Canada's Human Rights Act.” National Post, June 27, 2013. https://nationalpost.com/news/politics/hate-speech-no-longe r-part-of-canadas-human-rights-act. 
